\title{
Synthesis of the Parent and Substituted Tetracyclic \\ ABCD Ring Cores of Camptothecins via
}

\section{1-(3-Aryl-2-propynyl)-1,6-dihydro-6-oxo-2-pyridinecarbonitriles}

\author{
Weixiang Dai, Jeffrey L. Petersen, and Kung K. Wang* \\ C. Eugene Bennett Department of Chemistry, West Virginia University \\ Morgantown, West Virginia 26506-6045
}

Supporting Information

Table of Contents

Page

S4 General Experimental Methods

S4 Experimental Procedure for 3-(2,3-Dimethoxyphenyl)-2-propyn-1-ol.

S5 Experimental Procedure for 3-Bromo-1-(2-methoxyphenyl)propyne.

S5 Experimental Procedure for 3-Bromo-1-(2,3-dimethoxyphenyl)propyne.

S6 $\quad$ Experimental Procedure for

1,6-Dihydro-6-oxo-1-(3-phenyl-2-propynyl)-2-pyridinecarbonitrile (3a).

S6 Experimental Procedure for 1,6-Dihydro-1-[3-(4-methoxyphenyl)-2propynyl]-6-oxo-2-pyridinecarbonitrile (3b).

S7 Experimental Procedure for 1,6-Dihydro-1-[3-(2-methoxyphenyl)-2propynyl]-6-oxo-2-pyridinecarbonitrile (3c).

S7 Experimental Procedure for 1,6-Dihydro-1-[3-(3-methoxyphenyl)-2propynyl]-6-oxo-2-pyridinecarbonitrile (3d). 
Experimental Procedure for 1,6-Dihydro-1-

[3-(2,3-dimethoxyphenyl)-2-propynyl]-6-oxo-2-pyridinecarbonitrile (3e).

S8 Experimental Procedure for Indolizino[1,2-b]quinolin-9(11H)-one (6a).

S9 Experimental Procedure for

3-Methoxyindolizino[1,2-b]quinolin-9(11H)-one (6b).

S9 Experimental Procedure for

1-Methoxyindolizino[1,2-b]quinolin-9(11H)-one (6c).

S10 Experimental Procedure for

4-Methoxyindolizino[1,2-b]quinolin-9(11H)-one (6d) and

2-Methoxyindolizino[1,2-b]quinolin-9(11H)-one $\left(\mathbf{6} \mathbf{d}^{\prime}\right)$.

S11 Experimental Procedure for

1,2-Dimethoxyindolizino[1,2-b]quinolin-9(11H)-one (6e).

S11 References

S12-S13 $\quad{ }^{1} \mathrm{H}$ and ${ }^{13} \mathrm{C}$ NMR Spectra of 3-(2,3-Dimethoxyphenyl)-2-propyn-1-ol.

S14-S15 $\quad{ }^{1} \mathrm{H}$ and ${ }^{13} \mathrm{C}$ NMR Spectra of 3-Bromo-1-(2-methoxyphenyl)propyne.

S16-S17 $\quad{ }^{1} \mathrm{H}$ and ${ }^{13} \mathrm{C}$ NMR Spectra of 3-Bromo-1-(2,3-dimethoxyphenyl)propyne.

S18-S19 $\quad{ }^{1} \mathrm{H}$ and ${ }^{13} \mathrm{C}$ NMR Spectra of

1,6-Dihydro-6-oxo-1-(3-phenyl-2-propynyl)-2-pyridinecarbonitrile (3a).

S20-S21 $\quad{ }^{1} \mathrm{H}$ and ${ }^{13} \mathrm{C}$ NMR Spectra of 1,6-Dihydro-1-[3-(4-methoxyphenyl)-2-

propynyl]-6-oxo-2-pyridinecarbonitrile (3b).

S22-S23 ${ }^{1} \mathrm{H}$ and ${ }^{13} \mathrm{C}$ NMR Spectra of 1,6-Dihydro-1-[3-(2-methoxyphenyl)-2-

propynyl]-6-oxo-2-pyridinecarbonitrile (3c). 
S24-S25 ${ }^{1} \mathrm{H}$ and ${ }^{13} \mathrm{C}$ NMR Spectra of 1,6-Dihydro-1-[3-(3-methoxyphenyl)-2propynyl]-6-oxo-2-pyridinecarbonitrile (3d).

S26-S27 ${ }^{1} \mathrm{H}$ and ${ }^{13} \mathrm{C}$ NMR Spectra of 1,6-Dihydro-1-[3-(2,3-dimethoxyphenyl)-2propynyl]-6-oxo-2-pyridinecarbonitrile (3e).

S28-S29 $\quad{ }^{1} \mathrm{H}$ and ${ }^{13} \mathrm{C}$ NMR Spectra of Indolizino[1,2-b]quinolin-9(11H)-one (6a).

S30-S31 $\quad{ }^{1} \mathrm{H}$ and ${ }^{13} \mathrm{C}$ NMR Spectra of

3-Methoxyindolizino[1,2-b]quinolin-9(11H)-one (6b).

S32-S33 $\quad{ }^{1} \mathrm{H}$ and ${ }^{13} \mathrm{C}$ NMR Spectra of

1-Methoxyindolizino[1,2-b]quinolin-9(11H)-one (6c).

S34-S35 $\quad{ }^{1} \mathrm{H}$ and ${ }^{13} \mathrm{C}$ NMR Spectra of

4-Methoxyindolizino[1,2-b]quinolin-9(11H)-one (6d).

S36 $\quad{ }^{1}$ H NMR Spectrum of

2-Methoxyindolizino[1,2-b]quinolin-9(11H)-one (6d').

S37-S38 $\quad{ }^{1} \mathrm{H}$ and ${ }^{13} \mathrm{C}$ NMR Spectra of

1,2-Dimethoxyindolizino[1,2-b]quinolin-9(11H)-one (6e).

S39 Figure S1. ORTEP Drawing of the Crystal Structure of

1,6-Dihydro-1-[3-(4-methoxyphenyl)-2-propynyl]-6-oxo-2-

pyridinecarbonitrile (3b).

S40 Figure S2. ORTEP Drawing of the Crystal Structure of Indolizino[1,2-b]quinolin-9(11H)-one (6a).

S41 Figure S3. ORTEP Drawing of the Crystal Structure of 4-Methoxyindolizino[1,2-b]quinolin-9(11H)-one (6d). 
All reactions were conducted in oven-dried $\left(120^{\circ} \mathrm{C}\right)$ glassware under a nitrogen atmosphere. 3-(2-Methoxyphenyl)-2-propyn-1-ol, ${ }^{21} 3$-bromo-1-phenylpropyne, ${ }^{22} 3$ bromo-1-(4-methoxyphenyl)propyne, ${ }^{23}$ and 3-bromo-1-(3-methoxyphenyl)propyne ${ }^{24}$ were prepared according to the reported procedures. Propargyl alcohol, 1-iodo-2,3dimethoxybenzene, triethylamine, $\mathrm{Pd}\left(\mathrm{PPh}_{3}\right)_{2} \mathrm{Cl}_{2}$, copper(I) iodide, methanesulfonyl chloride, lithium bromide, 1,2-dimethoxyethane (DME), $N, N$-dimethylformamide (DMF), 60\% sodium hydride dispersion in mineral oil, 1,8-diazabicyclo[5.4.0]undec-7ene (DBU), and 1,2-dichlorobenzene were purchased from chemical suppliers and were used as received. Melting points were uncorrected. ${ }^{1} \mathrm{H}(270 \mathrm{MHz})$ and ${ }^{13} \mathrm{C}(67.9 \mathrm{MHz})$ NMR spectra were recorded in $\mathrm{CDCl}_{3}$ using $\mathrm{CHCl}_{3}\left({ }^{1} \mathrm{H} \delta\right.$ 7.26) and $\mathrm{CDCl}_{3}\left({ }^{13} \mathrm{C} \delta 77.00\right)$ as internal standards.

3-(2,3-Dimethoxyphenyl)-2-propyn-1-ol. To a mixture of 1-iodo-2,3dimethoxybenzene (528 mg, $2.0 \mathrm{mmol}), \mathrm{Pd}\left(\mathrm{PPh}_{3}\right)_{2} \mathrm{Cl}_{2}(70 \mathrm{mg}, 0.10 \mathrm{mmol})$, and copper(I) iodide (38 $\mathrm{mg}, 0.20 \mathrm{mmol}$ ) in $25 \mathrm{~mL}$ of triethylamine under a nitrogen atmosphere was added dropwise via cannula a solution of $224 \mathrm{mg}$ of propargyl alcohol $(4.0 \mathrm{mmol})$ in 5 $\mathrm{mL}$ of triethylamine. The reaction mixture was stirred vigorously at $90{ }^{\circ} \mathrm{C}$ for $12 \mathrm{~h}$ before it was allowed to cool to room temperature. Then $50 \mathrm{~mL}$ of a saturated $\mathrm{NH}_{4} \mathrm{Cl}$ solution and $50 \mathrm{~mL}$ of diethyl ether were introduced. The organic layer was separated, and the aqueous layer was back extracted with diethyl ether. The combined organic layers were washed with water, dried over $\mathrm{MgSO}_{4}$, and concentrated. The residue was purified by column chromatography (silica gel/diethyl ether:hexanes $=1: 1$ ) to give 180 $\mathrm{mg}(0.94 \mathrm{mmol}, 47 \%)$ of 3-(2,3-dimethoxyphenyl)-2-propyn-1-ol as a pale yellow liquid: IR 3420, 2227, 1470, 1260, $1096 \mathrm{~cm}^{-1} ;{ }^{1} \mathrm{H} \delta 7.04-6.86(3 \mathrm{H}, \mathrm{m}), 4.53(2 \mathrm{H}, \mathrm{s}), 3.92(3 \mathrm{H}$, 
s), $3.86(3 \mathrm{H}, \mathrm{s}), 1.80(1 \mathrm{H}$, br s $) ;{ }^{13} \mathrm{C} \delta 152.6,150.4,125.1,123.9,117.2,113.1,91.2$, $81.7,61.0,55.9,51.8$.

3-Bromo-1-(2-methoxyphenyl)propyne. To a solution of 3-(2-methoxyphenyl)-2propyn-1-ol (648 mg, $4.0 \mathrm{mmol})$ and triethylamine $(607 \mathrm{mg}, 5.8 \mathrm{mmol})$ in $20 \mathrm{~mL}$ of methylene chloride at $-50^{\circ} \mathrm{C}$ under a nitrogen atmosphere was added dropwise methanesulfonyl chloride $(596 \mathrm{mg}, 5.2 \mathrm{mmol})$. The reaction mixture was allowed to warm to room temperature and stirred for $1 \mathrm{~h}$ before lithium bromide (3.5 g, $41 \mathrm{mmol})$ in $20 \mathrm{~mL}$ of THF was added. After an additional $12 \mathrm{~h}$ at room temperature, $10 \mathrm{~mL}$ of water was introduced. The organic layer was separated, and the aqueous layer was back extracted with methylene chloride. The combined organic layers were washed with water, dried over $\mathrm{MgSO}_{4}$, and concentrated. The residue was purified by column chromatography (silica gel/diethyl ether:hexanes $=1: 10)$ to give $801 \mathrm{mg}(3.6 \mathrm{mmol}$, 89\%) of 3-bromo-1-(2-methoxyphenyl)propyne as a colorless liquid: IR 2217, 1491, $1270,749 \mathrm{~cm}^{-1} ;{ }^{1} \mathrm{H} \delta 7.42(1 \mathrm{H}, \mathrm{dd}, J=7.7,1.7 \mathrm{~Hz}), 7.31(1 \mathrm{H}, \mathrm{td}, J=8.2,1.7 \mathrm{~Hz})$, 6.96-6.82 (2 H, m), $4.23(2 \mathrm{H}, \mathrm{s}), 3.87(3 \mathrm{H}, \mathrm{s}) ;{ }^{13} \mathrm{C} \delta 160.1,133.9,130.3,120.4,111.1$, $110.5,88.1,83.1,55.7,15.8$.

3-Bromo-1-(2,3-dimethoxyphenyl)propyne. To a solution of 3-(2,3-dimethoxyphenyl)2-propyn-1-ol (170 mg, $0.89 \mathrm{mmol})$ and triethylamine $(135 \mathrm{mg}, 1.3 \mathrm{mmol})$ in $10 \mathrm{~mL}$ of methylene chloride at $-50^{\circ} \mathrm{C}$ under a nitrogen atmosphere was added dropwise methanesulfonyl chloride $(133 \mathrm{mg}, 1.2 \mathrm{mmol})$. The reaction mixture was allowed to warm to room temperature and stirred for $1 \mathrm{~h}$ before lithium bromide (783 $\mathrm{mg}, 9.1 \mathrm{mmol})$ in $10 \mathrm{~mL}$ of THF was added. After an additional $12 \mathrm{~h}$ at room temperature, $5 \mathrm{~mL}$ of water was introduced. The organic layer was separated, and the aqueous layer was back 
extracted with methylene chloride. The combined organic layers were washed with water, dried over $\mathrm{MgSO}_{4}$, and concentrated. The residue was purified by column chromatography (silica gel/diethyl ether:hexanes $=1: 10)$ to give $181 \mathrm{mg}(0.71 \mathrm{mmol}$, 80\%) of 3-bromo-1-(2,3-dimethoxyphenyl)propyne as a colorless liquid: IR 2229, 1470, $1262,1102 \mathrm{~cm}^{-1} ;{ }^{1} \mathrm{H} \delta 7.03-6.86(3 \mathrm{H}, \mathrm{m}), 4.21(2 \mathrm{H}, \mathrm{s}), 3.93(3 \mathrm{H}, \mathrm{s}), 3.86(3 \mathrm{H}, \mathrm{s}) ;{ }^{13} \mathrm{C}$ $\delta 152.6,150.7,125.2,123.8,116.8,113.4,88.0,82.9,61.2,55.9,15.5$.

\section{1,6-Dihydro-6-oxo-1-(3-phenyl-2-propynyl)-2-pyridinecarbonitrile (3a). To a} solution of 1,6-dihydro-6-oxo-2-pyridinecarbonitrile (2,120 mg, $1.0 \mathrm{mmol})$ in DME (2.0 $\mathrm{mL})$ and $\mathrm{DMF}(0.5 \mathrm{~mL})$ under a nitrogen atmosphere was added $42 \mathrm{mg}$ of a $60 \%$ sodium hydride $(1.1 \mathrm{mmol})$ dispersion in mineral oil at $0{ }^{\circ} \mathrm{C}$. After $10 \mathrm{~min}$, lithium bromide (174 $\mathrm{mg}, 2.0 \mathrm{mmol}$ ) was added. The reaction mixture was stirred at room temperature for 15 min before 3-bromo-1-phenylpropyne (390 $\mathrm{mg}, 2.0 \mathrm{mmol}$ ) was added. The reaction mixture was then heated at $65^{\circ} \mathrm{C}$ for $15 \mathrm{~h}$ before it was allowed to cool to room temperature. The mixture was poured into brine $(50 \mathrm{~mL})$, extracted with ethyl acetate (2 $\times 50 \mathrm{~mL}$ ), dried over sodium sulfate, and concentrated. The residue was purified by column chromatography (silica gel/ethyl acetate) to give $201 \mathrm{mg}(0.86 \mathrm{mmol}, 86 \%)$ of 3a as a white solid: $\mathrm{mp} 104-105{ }^{\circ} \mathrm{C}$; IR $2222,1655,1586,758 \mathrm{~cm}^{-1} ;{ }^{1} \mathrm{H} \delta 7.48-7.38(2 \mathrm{H}$, m), 7.36-7.21 (4 H, m), $6.84(1 \mathrm{H}, \mathrm{dd}, J=9.4,1.2 \mathrm{~Hz}), 6.77(1 \mathrm{H}, \mathrm{dd}, J=6.9,1.5 \mathrm{~Hz})$, $5.14(2 \mathrm{H}, \mathrm{s}) ;{ }^{13} \mathrm{C} \delta 160.1,137.6,132.0,128.8,128.2,127.4,121.8,120.7,116.2,112.3$, $85.3,81.7,36.7$.

\section{1,6-Dihydro-1-[3-(4-methoxyphenyl)-2-propynyl]-6-oxo-2-pyridinecarbonitrile (3b).}

The same procedure was repeated as described for 3a except that 3-bromo-1-(4methoxyphenyl)propyne (450 mg, $2.0 \mathrm{mmol})$ was used to give $243 \mathrm{mg}(0.92 \mathrm{mmol}, 92 \%)$ 
of $\mathbf{3 b}$ as a white solid: $\mathrm{mp} 130-131^{\circ} \mathrm{C}$; IR 2221, 1656, $1510,800 \mathrm{~cm}^{-1} ;{ }^{1} \mathrm{H} \delta 7.42-7.25$ (3 H, m), 6.89-6.73 (4 H, m), $5.13(2 \mathrm{H}, \mathrm{s}), 3.77(3 \mathrm{H}, \mathrm{s}) ;{ }^{13} \mathrm{C} \delta 160.1,160.0,137.6$, $133.5,127.4,120.6,116.2,113.8,112.3,85.2,80.3,55.2,36.8$. Recrystallization from a mixture of methylene chloride and hexanes produced a single crystal suitable for X-ray structure analysis.

\section{1,6-Dihydro-1-[3-(2-methoxyphenyl)-2-propynyl]-6-oxo-2-pyridinecarbonitrile (3c).}

The same procedure was repeated as described for 3a except that 3-bromo-1-(2methoxyphenyl)propyne $(450 \mathrm{mg}, 2.0 \mathrm{mmol})$ was used to give $227 \mathrm{mg}(0.86 \mathrm{mmol}, 86 \%)$

of 3c as a pale yellow solid: $\mathrm{mp} 136-137{ }^{\circ} \mathrm{C}$; IR $2234,1660,1581,756 \mathrm{~cm}^{-1} ;{ }^{1} \mathrm{H} \delta 7.41$ (1 H, dd, $J=7.4,1.7 \mathrm{~Hz}), 7.36-7.24(2 \mathrm{H}, \mathrm{m}), 6.92-6.81(3 \mathrm{H}, \mathrm{m}), 6.78(1 \mathrm{H}, \mathrm{dd}, J=6.7$, $1.2 \mathrm{~Hz}), 5.21(2 \mathrm{H}, \mathrm{s}), 3.85(3 \mathrm{H}, \mathrm{s}) ;{ }^{13} \mathrm{C} \delta 160.4,160.1,137.6,134.0,130.3,127.4,120.8$, $120.3,116.2,112.3,111.0,110.6,85.6,81.9,55.7,36.9$.

\section{1,6-Dihydro-1-[3-(3-methoxyphenyl)-2-propynyl]-6-oxo-2-pyridinecarbonitrile (3d).}

The same procedure was repeated as described for 3a except that 3-bromo-1-(3methoxyphenyl)propyne (450 mg, $2.0 \mathrm{mmol})$ was used to give $222 \mathrm{mg}(0.84 \mathrm{mmol}, 84 \%)$ of 3d as a white solid: $\mathrm{mp} 95-96{ }^{\circ} \mathrm{C}$; IR $2224,1668,1593,801 \mathrm{~cm}^{-1} ;{ }^{1} \mathrm{H} \delta 7.32(1 \mathrm{H}$, dd, $J=9.4,6.7 \mathrm{~Hz}), 7.18(1 \mathrm{H}, \mathrm{t}, J=7.9 \mathrm{~Hz}), 7.02(1 \mathrm{H}, \mathrm{dt}, J=7.7,1.1 \mathrm{~Hz}), 6.95(1 \mathrm{H}, \mathrm{dd}, J$ $=2.5,1.5 \mathrm{~Hz}), 6.90-6.81(2 \mathrm{H}, \mathrm{m}), 6.77(1 \mathrm{H}, \mathrm{dd}, J=6.7,1.2 \mathrm{~Hz}), 5.14(2 \mathrm{H}, \mathrm{s}), 3.75(3$ $\mathrm{H}, \mathrm{s}) ;{ }^{13} \mathrm{C} \delta 160.0,159.1,137.7,129.2,127.4,124.4,122.6,120.6,116.5,116.2,115.5$, $112.3,85.1,81.4,55.2,36.6$.

\section{1,6-Dihydro-1-[3-(2,3-dimethoxyphenyl)-2-propynyl]-6-oxo-2-pyridinecarbonitrile}

(3e). To a solution of 1,6-dihydro-6-oxo-2-pyridinecarbonitrile (2, $48 \mathrm{mg}, 0.40 \mathrm{mmol})$ in DME (1.0 mL) and DMF (0.25 mL) under a nitrogen atmosphere was added $17 \mathrm{mg}$ of a 
$60 \%$ sodium hydride $(0.42 \mathrm{mmol})$ dispersion in mineral oil at $0{ }^{\circ} \mathrm{C}$. After $10 \mathrm{~min}$, lithium bromide (70 $\mathrm{mg}, 0.80 \mathrm{mmol}$ ) was added. The reaction mixture was stirred at room temperature for $15 \mathrm{~min}$ before 3-bromo-1-(2,3-dimethoxyphenyl)propyne (204 mg, 0.80 mmol) was added. The reaction mixture was then heated at $65^{\circ} \mathrm{C}$ for $15 \mathrm{~h}$ before it was allowed to cool to room temperature. The mixture was poured into brine $(20 \mathrm{~mL})$, extracted with ethyl acetate $(2 \times 20 \mathrm{~mL})$, dried over sodium sulfate, and concentrated. The residue was purified by column chromatography (silica gel/ethyl acetate) to give 89 $\mathrm{mg}(0.30 \mathrm{mmol}, 76 \%)$ of $\mathbf{3 e}$ as a white solid: $\mathrm{mp} 124-125^{\circ} \mathrm{C}$; IR $2230,1663,1100,806$ $\mathrm{cm}^{-1} ;{ }^{1} \mathrm{H} \delta 7.33(1 \mathrm{H}, \mathrm{dd}, J=9.4,6.7 \mathrm{~Hz}), 7.03-6.82(4 \mathrm{H}, \mathrm{m}), 6.78(1 \mathrm{H}, \mathrm{dd}, J=6.7,1.2$ $\mathrm{Hz}), 5.19(2 \mathrm{H}, \mathrm{s}), 3.89(3 \mathrm{H}, \mathrm{s}), 3.82(3 \mathrm{H}, \mathrm{s}) ;{ }^{13} \mathrm{C} \delta 160.1,152.6,150.8,137.7,127.4$, 125.2, 123.7, 120.7, 116.4, 116.2, 113.4, 112.3, 85.6, 81.5, 61.1, 55.9, 36.9.

Indolizino[1,2-b]quinolin-9(11H)-one (6a). ${ }^{7,9}$ To a solution of $\mathbf{3 a}(50 \mathrm{mg}, 0.21 \mathrm{mmol})$ in $4 \mathrm{~mL}$ of 1,2-dichlorobenzene was added $0.1 \mathrm{~mL}$ of a $0.1 \mathrm{M}$ solution of $\mathrm{DBU}(0.01$ mmol) in 1,2-dichlorobenzene. The reaction mixture was heated at $110{ }^{\circ} \mathrm{C}$ for $12 \mathrm{~h}$. The reaction was followed by TLC analysis and was found to have progressed to completion after $12 \mathrm{~h}$. The reaction mixture was allowed to cool to room temperature and then purified by column chromatography (silica gel/ethyl acetate:methanol $=6: 1$ ) to give $\mathbf{6 a}$ (50 $\mathrm{mg}, 0.21 \mathrm{mmol})$ in quantitative yield as a pale orange solid.

Alternatively, a flask containing a solution of $\mathbf{3 a}(50 \mathrm{mg}, 0.21 \mathrm{mmol})$ and DBU (32 mg, $0.21 \mathrm{mmol}$ ) in $4 \mathrm{~mL}$ of 1,2-dichlorobenzene under a nitrogen atmosphere was heated in an oil bath. When the temperature of the oil bath reached $120^{\circ} \mathrm{C}$ in about two hours, the flask was removed from the oil bath, and the reaction mixture was allowed to cool to room temperature. The reaction mixture was then purified by column 
chromatography (silica gel/ethyl acetate:methanol $=6: 1)$ to give $\mathbf{6 a}(50 \mathrm{mg}, 0.21 \mathrm{mmol})$ in quantitative yield as a pale orange solid: $\mathrm{mp} 252-253^{\circ} \mathrm{C}$ (lit. ${ }^{7} 253-254{ }^{\circ} \mathrm{C}$ ) ; IR 1666 , 1599, $784 \mathrm{~cm}^{-1} ;{ }^{1} \mathrm{H} \delta 8.31(1 \mathrm{H}, \mathrm{s}), 8.18(1 \mathrm{H}, \mathrm{d}, J=8.6 \mathrm{~Hz}), 7.87(1 \mathrm{H}, \mathrm{d}, J=8.2 \mathrm{~Hz})$, $7.78(1 \mathrm{H}, \mathrm{td}, J=6.9,1.5 \mathrm{~Hz}), 7.65(1 \mathrm{H}, \mathrm{dd}, J=9.2,6.9 \mathrm{~Hz}), 7.61(1 \mathrm{H}, \mathrm{td}, J=7.6,1.0$ Hz), $7.28(1 \mathrm{H}, \mathrm{d}, J=6.9 \mathrm{~Hz}), 6.71(1 \mathrm{H}, \mathrm{dd}, J=8.9,0.5 \mathrm{~Hz}), 5.22(2 \mathrm{H}, \mathrm{s}) ;{ }^{13} \mathrm{C} \delta 161.5$, $152.8,148.7,146.0,140.3,130.9,130.3,129.5,128.5,128.02,127.97,127.6,120.5$, 100.9, 49.9. Recrystallization of $\mathbf{6 a}$ from a mixture of methylene chloride and hexanes produced a single crystal suitable for X-ray structure analysis.

3-Methoxyindolizino[1,2-b]quinolin-9(11H)-one (6b). A flask containing a solution of 3b (50 mg, $0.19 \mathrm{mmol})$ and DBU (29 mg, $0.19 \mathrm{mmol})$ in $4 \mathrm{~mL}$ of 1,2-dichlorobenzene under a nitrogen atmosphere was heated in an oil bath. When the temperature of the oil bath reached $120^{\circ} \mathrm{C}$ in about two hours, the flask was removed from the oil bath, and the reaction mixture was allowed to cool to room temperature. The reaction mixture was then purified by column chromatography (silica gel/ethyl acetate:methanol $=6: 1$ ) to give 6b (50 mg, $0.19 \mathrm{mmol})$ in quantitative yield as a pale yellow solid: $\mathrm{mp} 250-251{ }^{\circ} \mathrm{C}$; IR 1666, 1618, 1597, $1224 \mathrm{~cm}^{-1} ;{ }^{1} \mathrm{H} \delta 8.27(1 \mathrm{H}, \mathrm{s}), 7.77(1 \mathrm{H}, \mathrm{d}, J=9.2 \mathrm{~Hz}), 7.66(1 \mathrm{H}, \mathrm{dd}$, $J=8.9,6.9 \mathrm{~Hz}), 7.51(1 \mathrm{H}, \mathrm{s}), 7.34-7.24(2 \mathrm{H}, \mathrm{m}), 6.71(1 \mathrm{H}, \mathrm{d}, J=9.2 \mathrm{~Hz}), 5.21(2 \mathrm{H}$, s), $3.99(3 \mathrm{H}, \mathrm{s}) ;{ }^{13} \mathrm{C} \delta 161.5,152.6,150.3,146.0,140.3,130.9,128.9,126.6,123.5$, 121.3, 120.3, 106.9, 100.9, 55.7, 49.9; MS m/z $264\left(\mathrm{M}^{+}\right), 249$.

1-Methoxyindolizino[1,2-b]quinolin-9(11H)-one (6c). ${ }^{7}$ A flask containing a solution of $3 \mathbf{c}(50 \mathrm{mg}, 0.19 \mathrm{mmol})$ and DBU $(29 \mathrm{mg}, 0.19 \mathrm{mmol})$ in $4 \mathrm{~mL}$ of 1,2-dichlorobenzene under a nitrogen atmosphere was heated in an oil bath. When the temperature of the oil bath reached $120^{\circ} \mathrm{C}$ in about two hours, the flask was removed from the oil bath, and the 
reaction mixture was allowed to cool to room temperature. The reaction mixture was then purified by column chromatography (silica gel/ethyl acetate:methanol $=6: 1$ ) to give 6c (50 mg, $0.19 \mathrm{mmol})$ in quantitative yield as a pale yellow solid: $\mathrm{mp} 270-271{ }^{\circ} \mathrm{C}$ (lit. ${ }^{7}$ $\left.252-253{ }^{\circ} \mathrm{C}\right)$; IR 1657, 1589, 1570, $806 \mathrm{~cm}^{-1} ;{ }^{1} \mathrm{H} \delta 8.76(1 \mathrm{H}, \mathrm{s}), 7.77(1 \mathrm{H}, \mathrm{d}, J=8.4$ Hz), 7.73-7.62 (2 H, m), $7.28(1 \mathrm{H}, \mathrm{d}, J=6.5 \mathrm{~Hz}), 6.92(1 \mathrm{H}, \mathrm{d}, J=6.9 \mathrm{~Hz}), 6.72(1 \mathrm{H}$, $\mathrm{dd}, J=9.2,1.0 \mathrm{~Hz}), 5.22(2 \mathrm{H}, \mathrm{d}, J=0.7 \mathrm{~Hz}), 4.04(3 \mathrm{H}, \mathrm{s}) ;{ }^{13} \mathrm{C} \delta 161.5,155.1,152.9$, $149.4,146.1,140.2,130.3,127.6,125.8,121.4,120.45,120.36,105.1,100.9,55.8,50.0$.

\section{4-Methoxyindolizino[1,2-b]quinolin-9(11H)-one (6d) and 2-Methoxyindolizino[1,2-}

b]quinolin-9(11H)-one (6d'). ${ }^{14}$ A flask containing a solution of 3d (50 mg, 0.19 mmol) and DBU (29 mg, $0.19 \mathrm{mmol})$ in $4 \mathrm{~mL}$ of 1,2-dichlorobenzene under a nitrogen atmosphere was heated in an oil bath. When the temperature of the oil bath reached 120 ${ }^{\circ} \mathrm{C}$ in about two hours, the flask was removed from the oil bath, and the reaction mixture was allowed to cool to room temperature. The reaction mixture was then purified by column chromatography ( silica gel/ethyl acetate:methanol $=6: 1$ ) to give a mixture of $\mathbf{6 d}$ and $\mathbf{6} \mathbf{d}^{\prime}$ (6d: $\left.6 \mathbf{d}^{\prime}=4: 3,50 \mathrm{mg}, 0.19 \mathrm{mmol}\right)$ in quantitative yield as a pale yellow solid. Recrystallization of the mixture of $\mathbf{6} \mathbf{d}$ and $\mathbf{6} \mathbf{d}^{\prime}$ from methylene chloride/hexanes allowed the isolation of small amounts of relatively pure $\mathbf{6} \mathbf{d}$ and $\mathbf{6} \mathbf{d}^{\prime}$ for physical and spectroscopic measurements. 6d: $\mathrm{mp} 281-283{ }^{\circ} \mathrm{C}$; IR 1656, 1591, 1239, $758 \mathrm{~cm}^{-1} ;{ }^{1} \mathrm{H} \delta$ $8.35(1 \mathrm{H}, \mathrm{s}), 7.67(1 \mathrm{H}, \mathrm{dd}, J=8.9,6.9 \mathrm{~Hz}), 7.61-7.45(2 \mathrm{H}, \mathrm{m}), 7.40(1 \mathrm{H}, \mathrm{d}, J=6.9$ Hz), $7.15(1 \mathrm{H}, \mathrm{dd}, J=7.7,1.2 \mathrm{~Hz}), 6.72(1 \mathrm{H}, \mathrm{d}, J=8.9 \mathrm{~Hz}), 5.27(2 \mathrm{H}, \mathrm{s}), 4.14(3 \mathrm{H}, \mathrm{s})$; ${ }^{13} \mathrm{C} \delta 161.5,155.5,152.0,146.0,140.8,140.3,130.9,129.23,129.20,128.0,120.4$, 119.9, 108.5, 101.5, 56.3, 49.9; $\mathrm{MS} m / z 264\left(\mathrm{M}^{+}\right), 235$. The structure of $\mathbf{6 d}$ was established by X-ray structure analysis. $6 \mathbf{d}^{\prime}:{ }^{1} \mathrm{H} \delta 8.28(1 \mathrm{H}, \mathrm{s}), 8.16(1 \mathrm{H}, \mathrm{d}, J=9.4 \mathrm{~Hz})$, 
$7.68(1 \mathrm{H}, \mathrm{dd}, J=8.9,6.9 \mathrm{~Hz}), 7.47(1 \mathrm{H}, \mathrm{dd}, J=9.2,2.7 \mathrm{~Hz}), 7.33(1 \mathrm{H}, \mathrm{d}, J=6.9 \mathrm{~Hz})$,

$7.17(1 \mathrm{H}, \mathrm{d}, J=2.7 \mathrm{~Hz}), 6.72(1 \mathrm{H}, \mathrm{d}, J=8.9 \mathrm{~Hz}), 5.27(2 \mathrm{H}, \mathrm{s}), 3.98(3 \mathrm{H}, \mathrm{s})$.

1,2-Dimethoxyindolizino[1,2-b]quinolin-9(11H)-one (6e). A flask containing a

solution of 3e (50 mg, $0.17 \mathrm{mmol})$ and $\mathrm{DBU}(26 \mathrm{mg}, 0.17 \mathrm{mmol})$ in $4 \mathrm{~mL}$ of 1,2-

dichlorobenzene under a nitrogen atmosphere was heated in an oil bath. When the

temperature of the oil bath reached $120^{\circ} \mathrm{C}$ in about two hours, the flask was removed

from the oil bath, and the reaction mixture was allowed to cool to room temperature. The

reaction mixture was then purified by column chromatography (silica gel/ethyl

acetate:methanol $=6: 1)$ to give $6 \mathbf{e}(50 \mathrm{mg}, 0.17 \mathrm{mmol})$ in quantitative yield as a pale

yellow solid: mp $216-218^{\circ} \mathrm{C}$; IR 1659, 1595, 1262, 799, $736 \mathrm{~cm}^{-1} ;{ }^{1} \mathrm{H} \delta 8.61(1 \mathrm{H}, \mathrm{s})$,

$7.95(1 \mathrm{H}, \mathrm{d}, J=9.4 \mathrm{~Hz}), 7.64(1 \mathrm{H}, \mathrm{dd}, J=8.9,6.7 \mathrm{~Hz}), 7.57(1 \mathrm{H}, \mathrm{d}, J=9.4 \mathrm{~Hz}), 7.22$

$(1 \mathrm{H}, \mathrm{d}, J=6.2 \mathrm{~Hz}), 6.69(1 \mathrm{H}, \mathrm{d}, J=8.9 \mathrm{~Hz}), 5.23(2 \mathrm{H}, \mathrm{s}), 4.04(6 \mathrm{H}, \mathrm{s}) ;{ }^{13} \mathrm{C} \delta 161.5$,

$151.2,149.3,146.1,144.2,142.0,140.3,128.6,125.6,124.9,123.9,120.2,118.7,100.5$,

61.4, 56.7, 50.0; $\mathrm{MS} \mathrm{m/z} 294\left(\mathrm{M}^{+}\right), 279,250,236$.

References

(21) Liron, F.; Garrec, P. L.; Alami, M. Synlett 1999, 246-248.

(22) Zhao, L.; Lu, X.; Xu, W. J. Org. Chem. 2005, 70, 4059-4063.

(23) Yi, X.-H.; Meng, Y.; Hua, X.-G.; Li, C.-J. J. Org. Chem. 1998, 63, 7472-7480.

(24) Zhang, W.; Luo, Z.; Chen, C. H.-T.; Curran, D. P. J. Am. Chem. Soc. 2002, 124, $10443-10450$. 


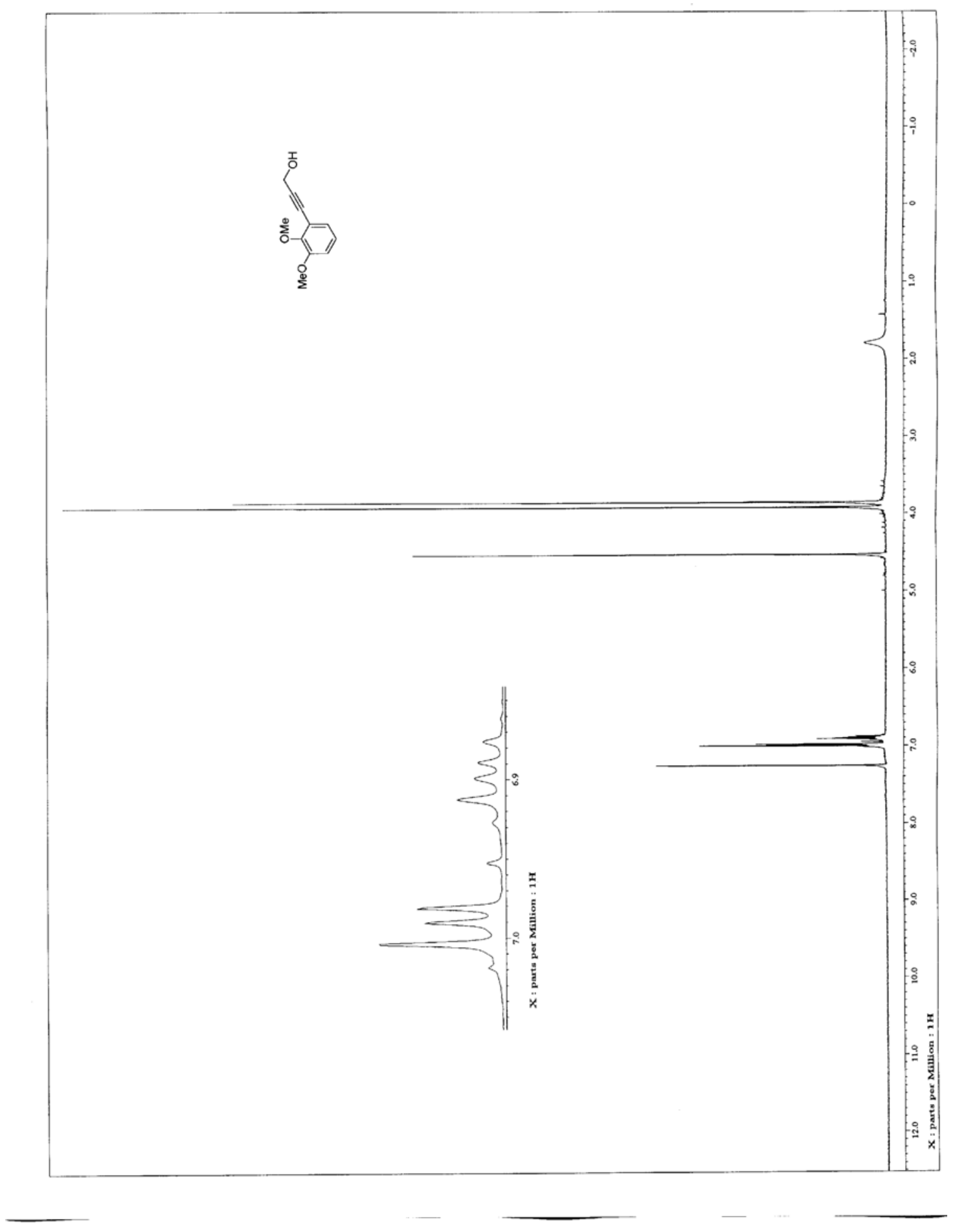




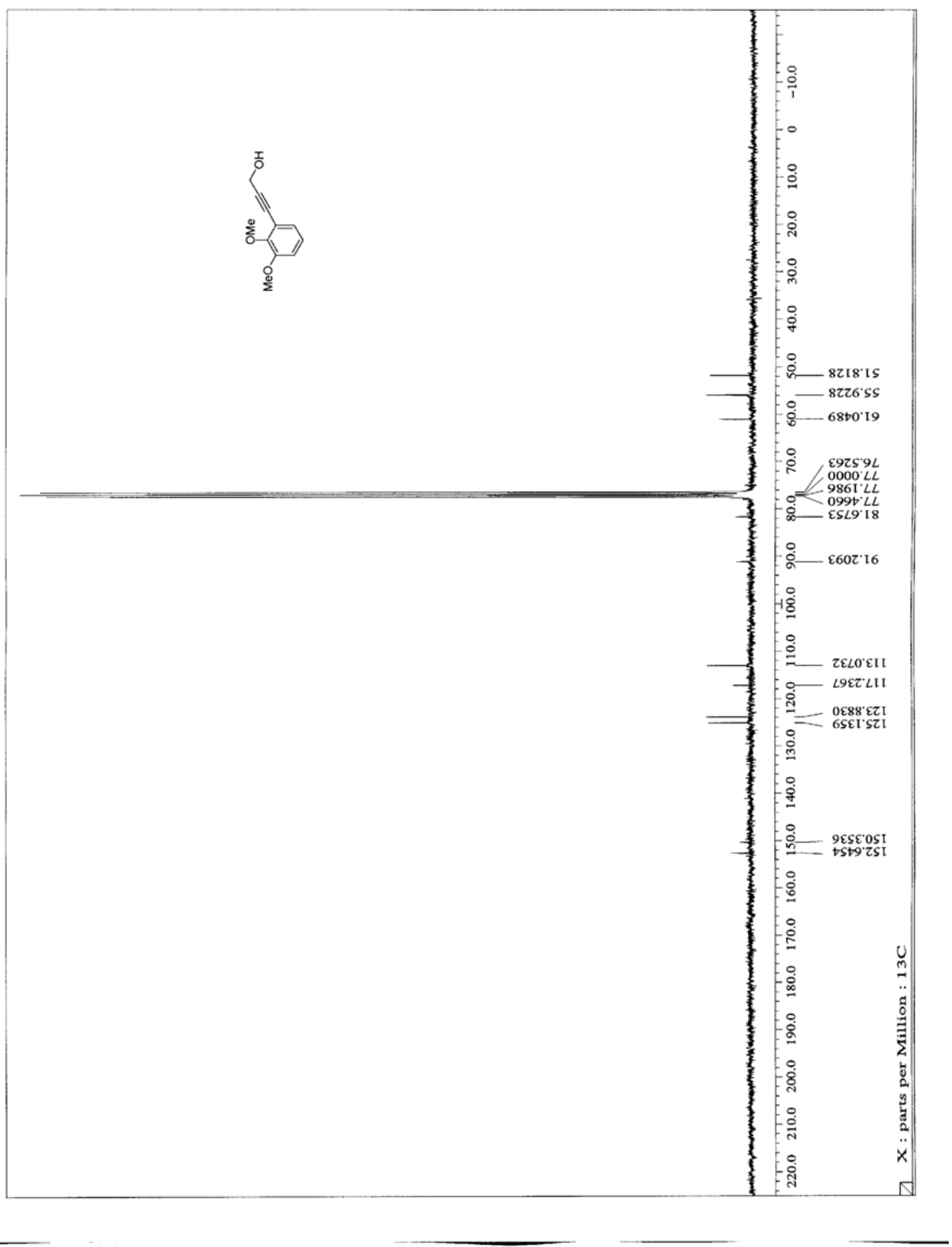




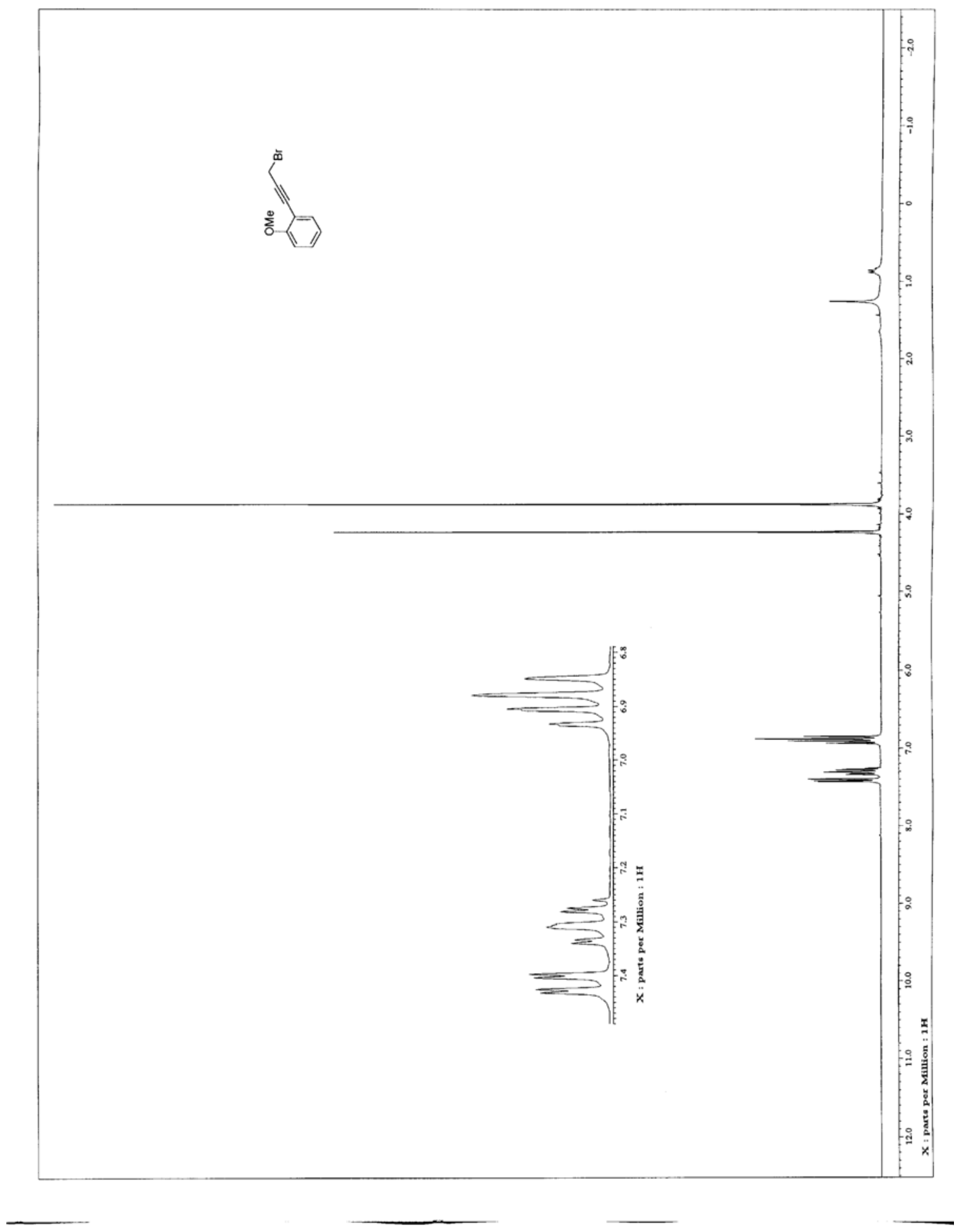

S14 


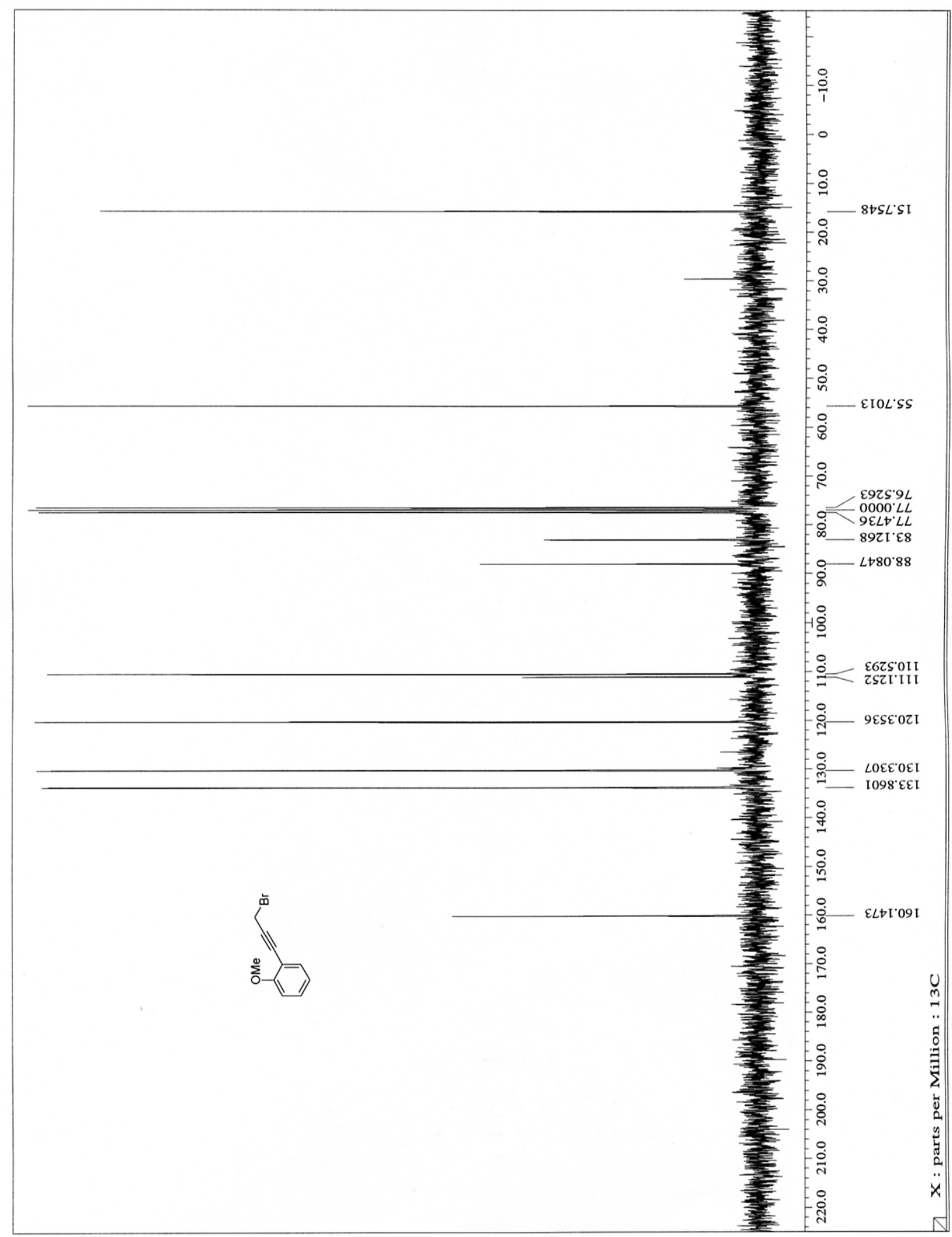




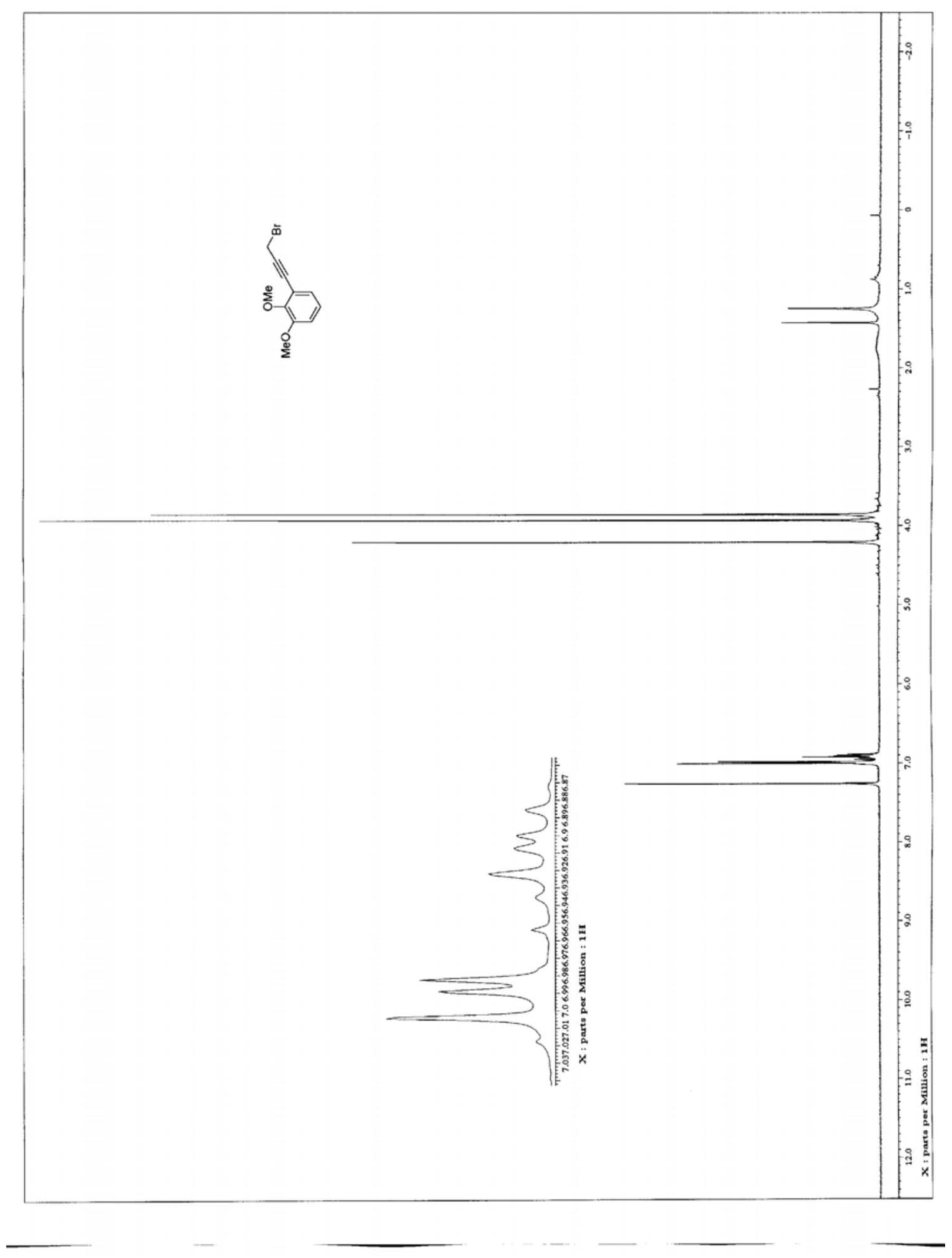

S16 


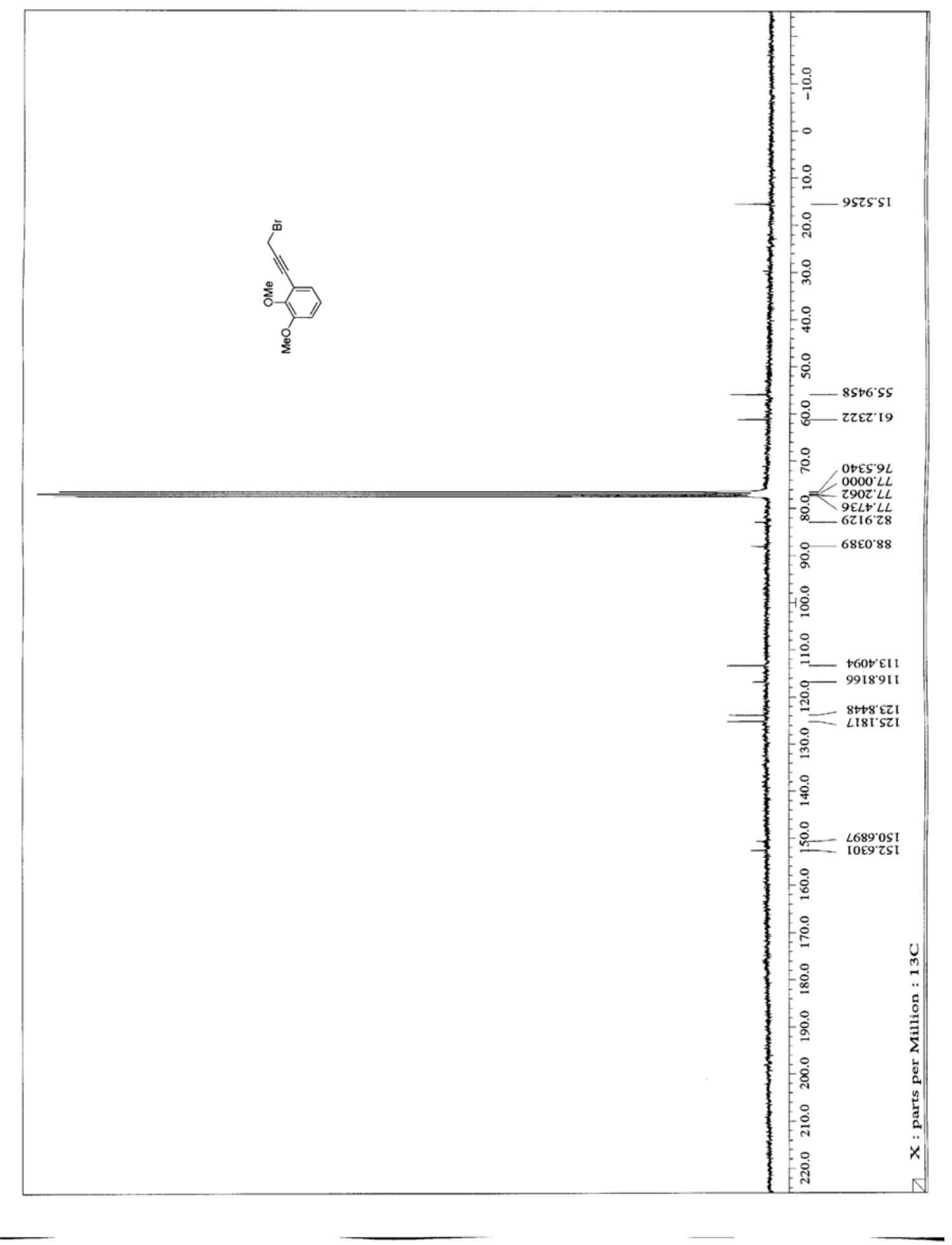




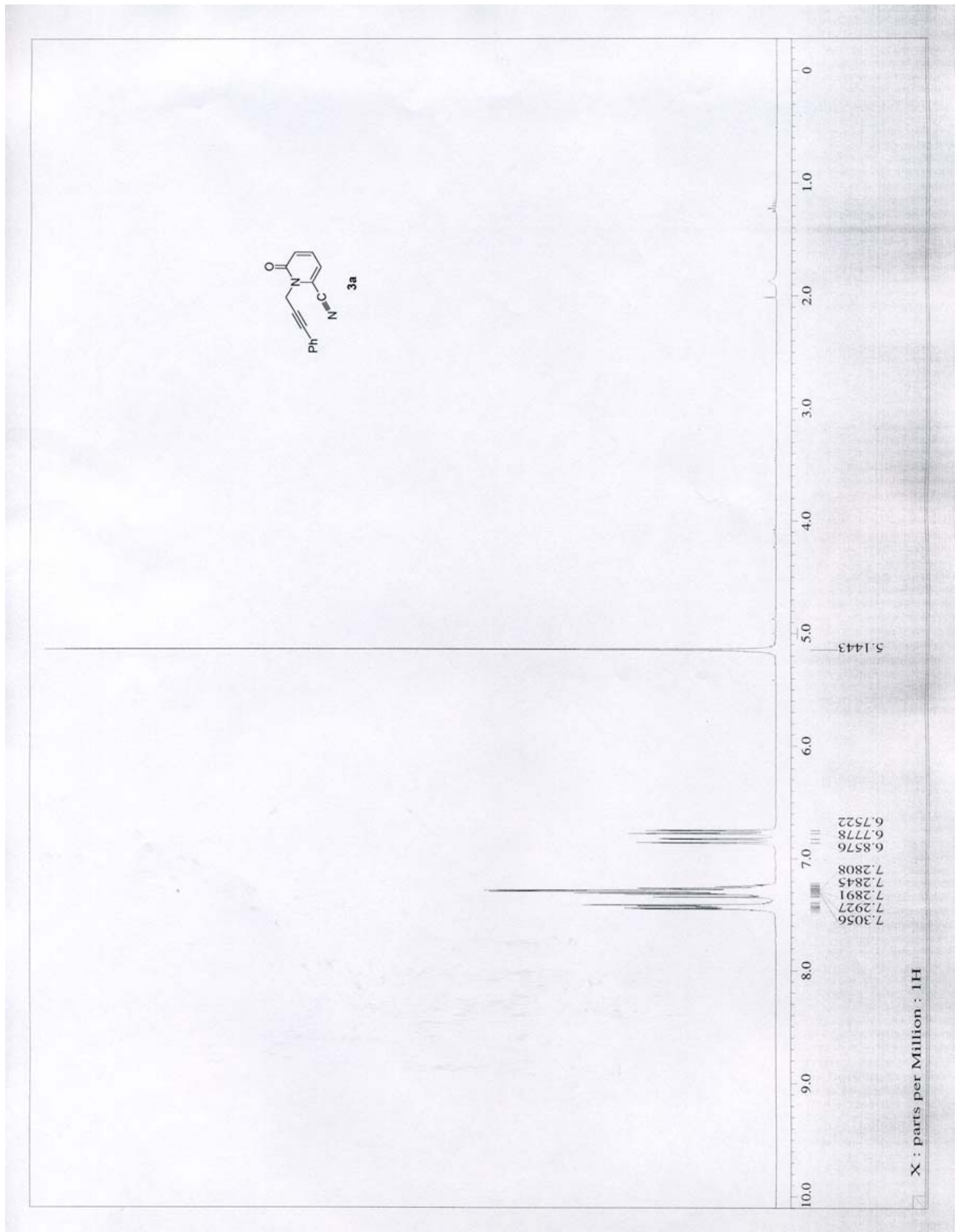

S18 


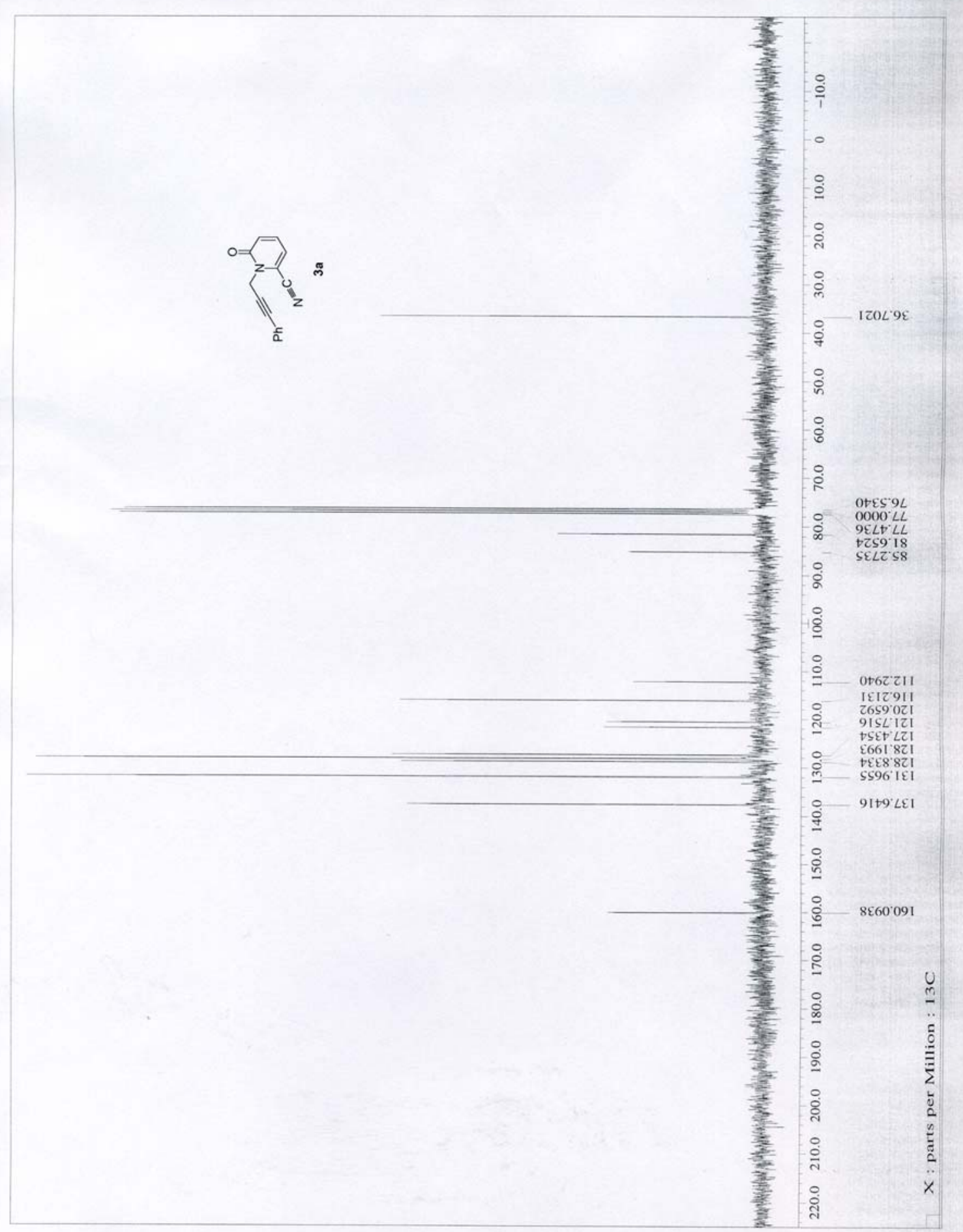




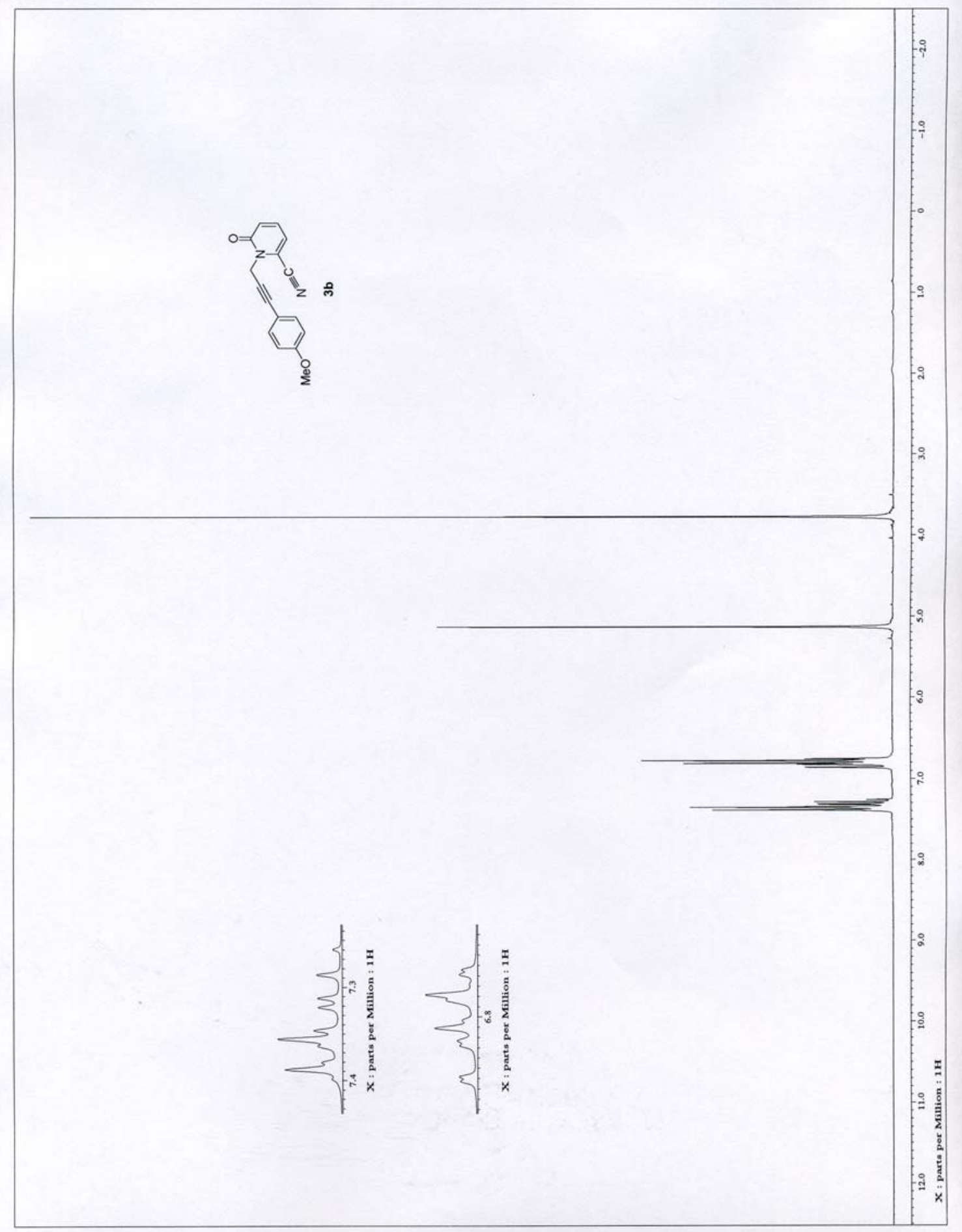




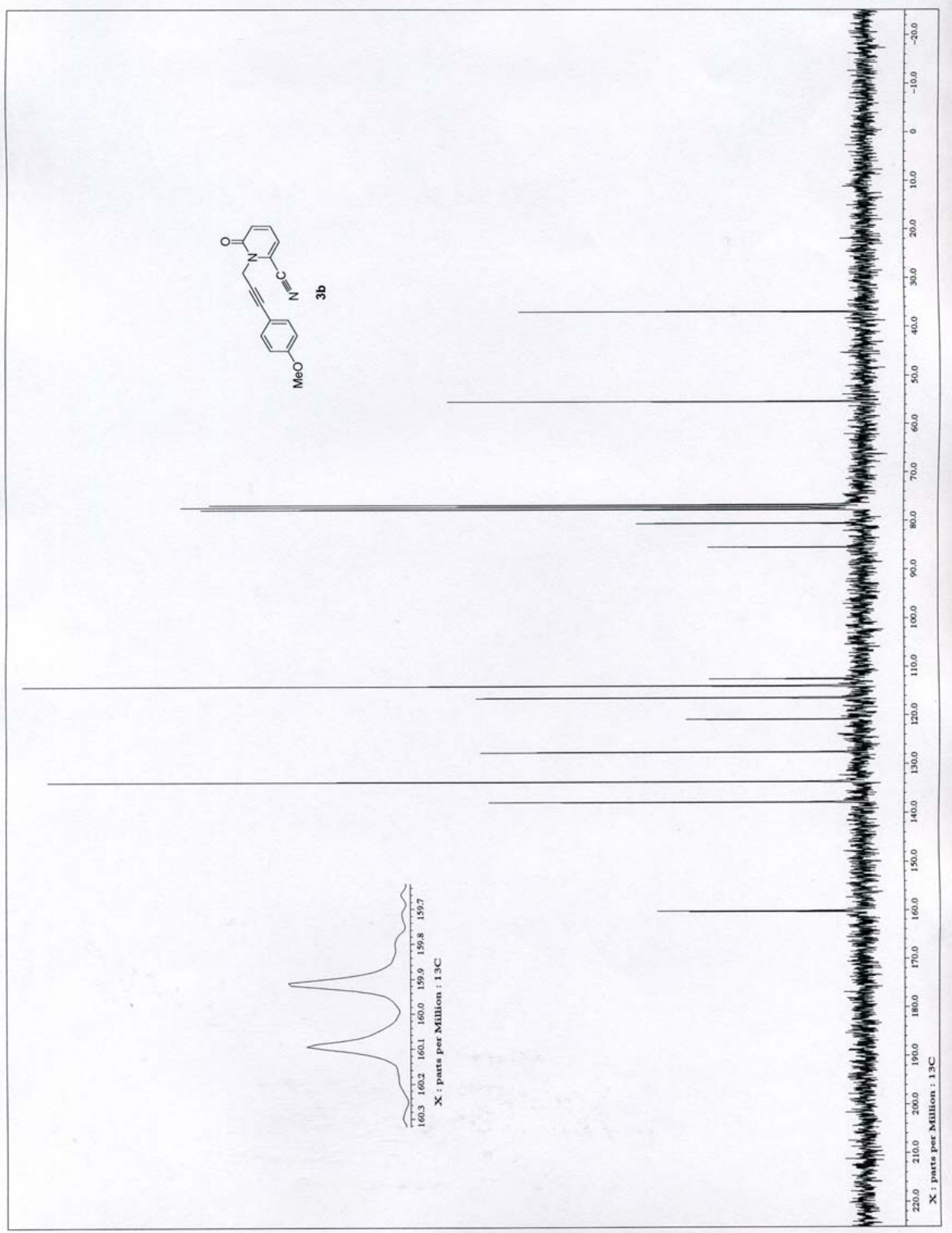




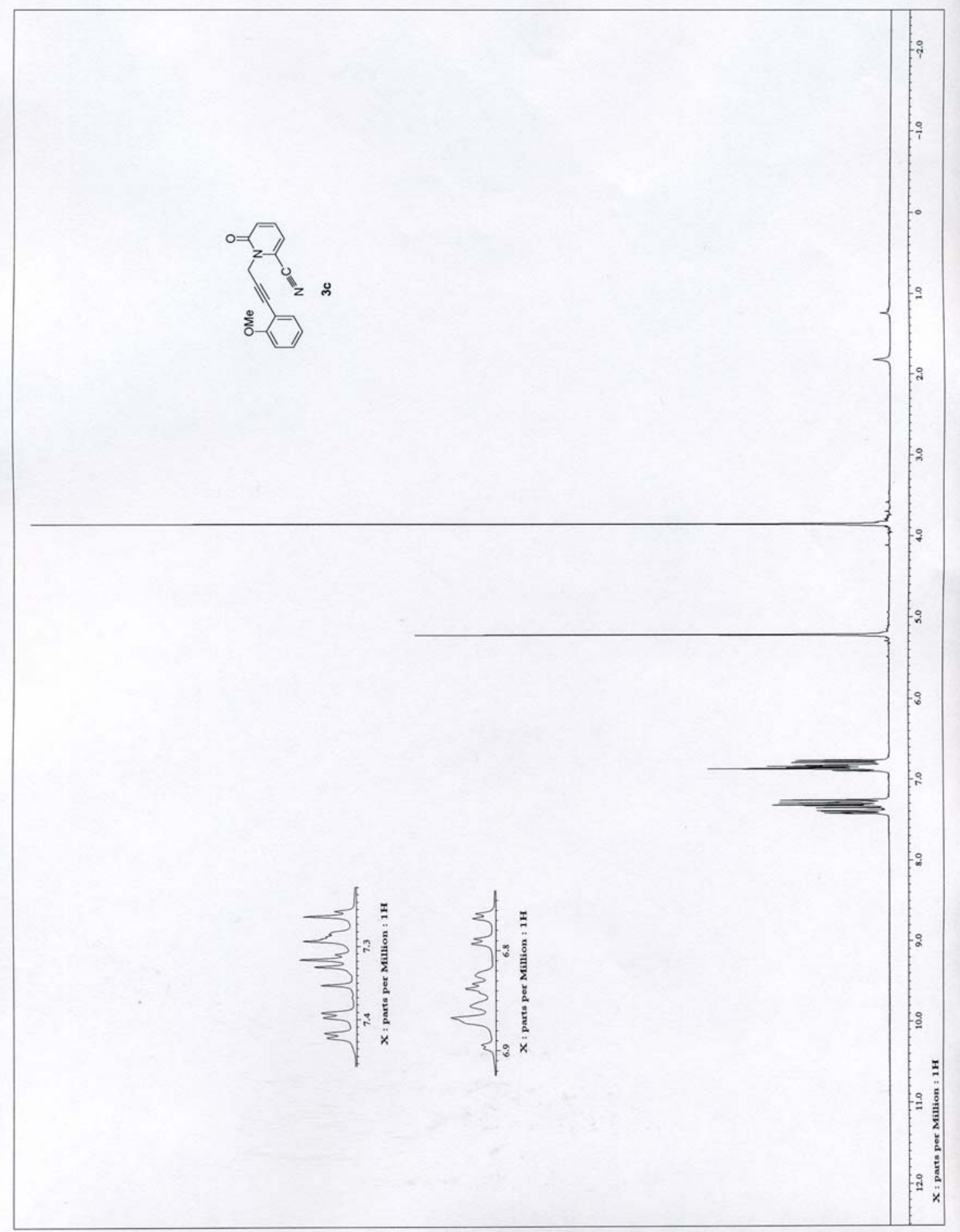




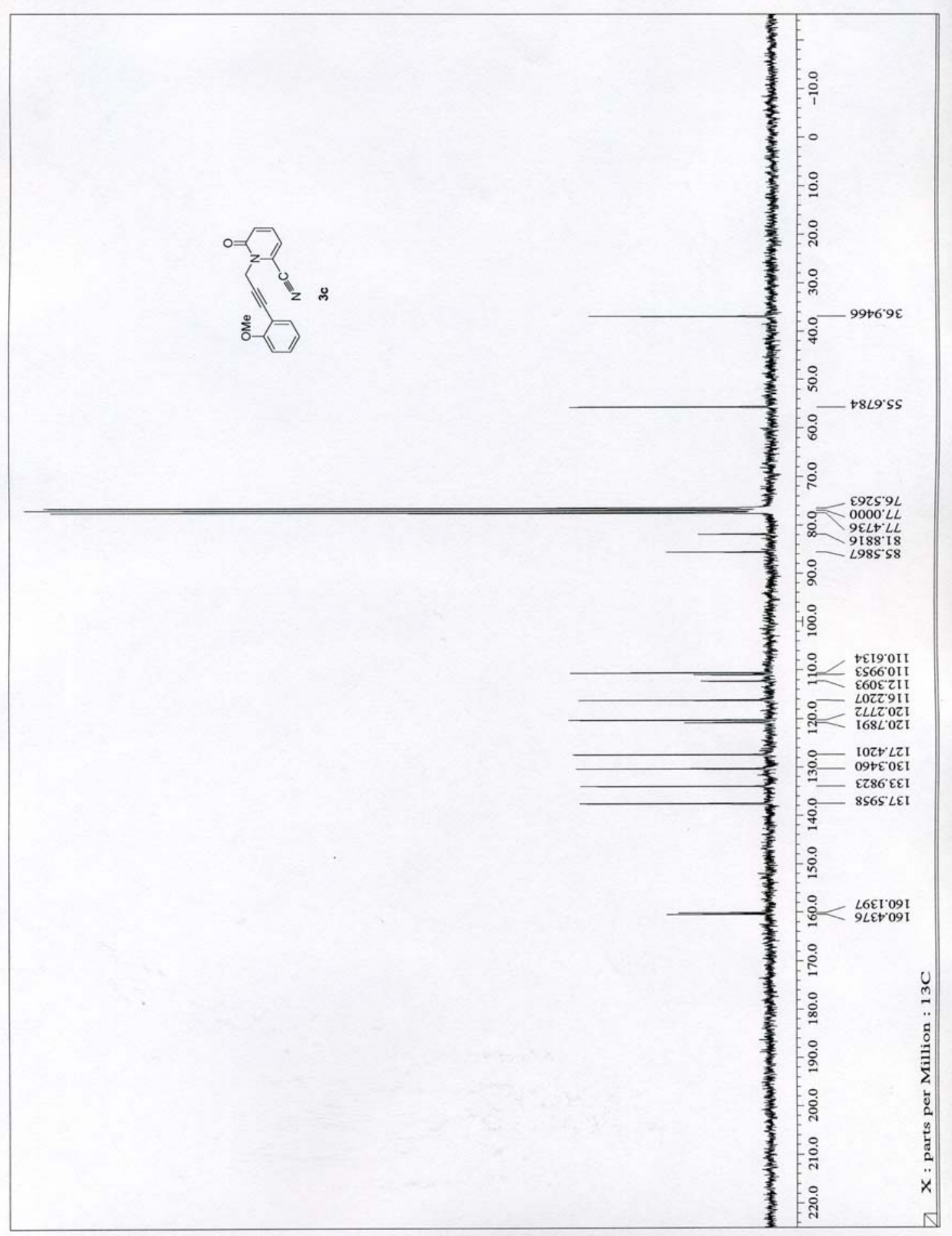




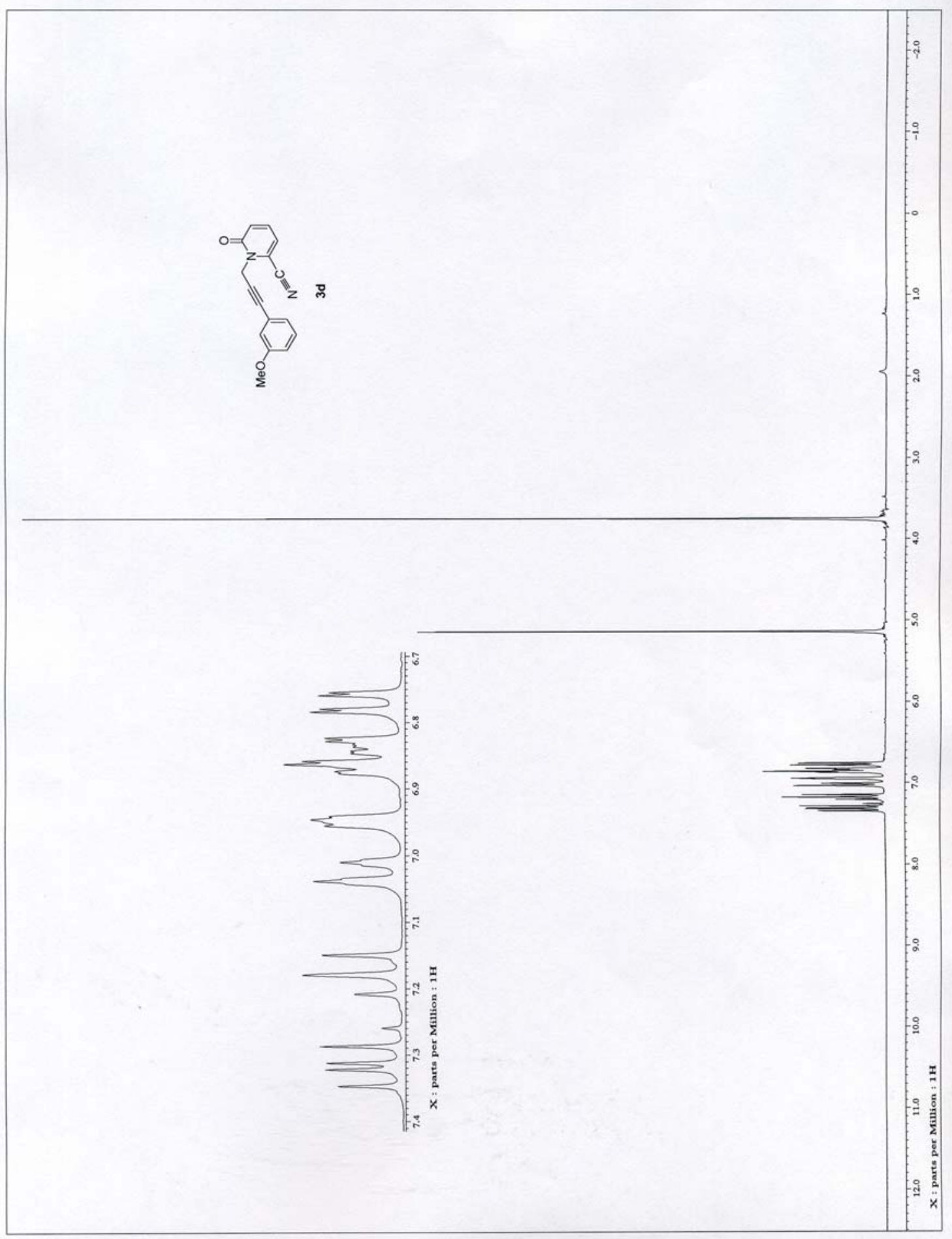




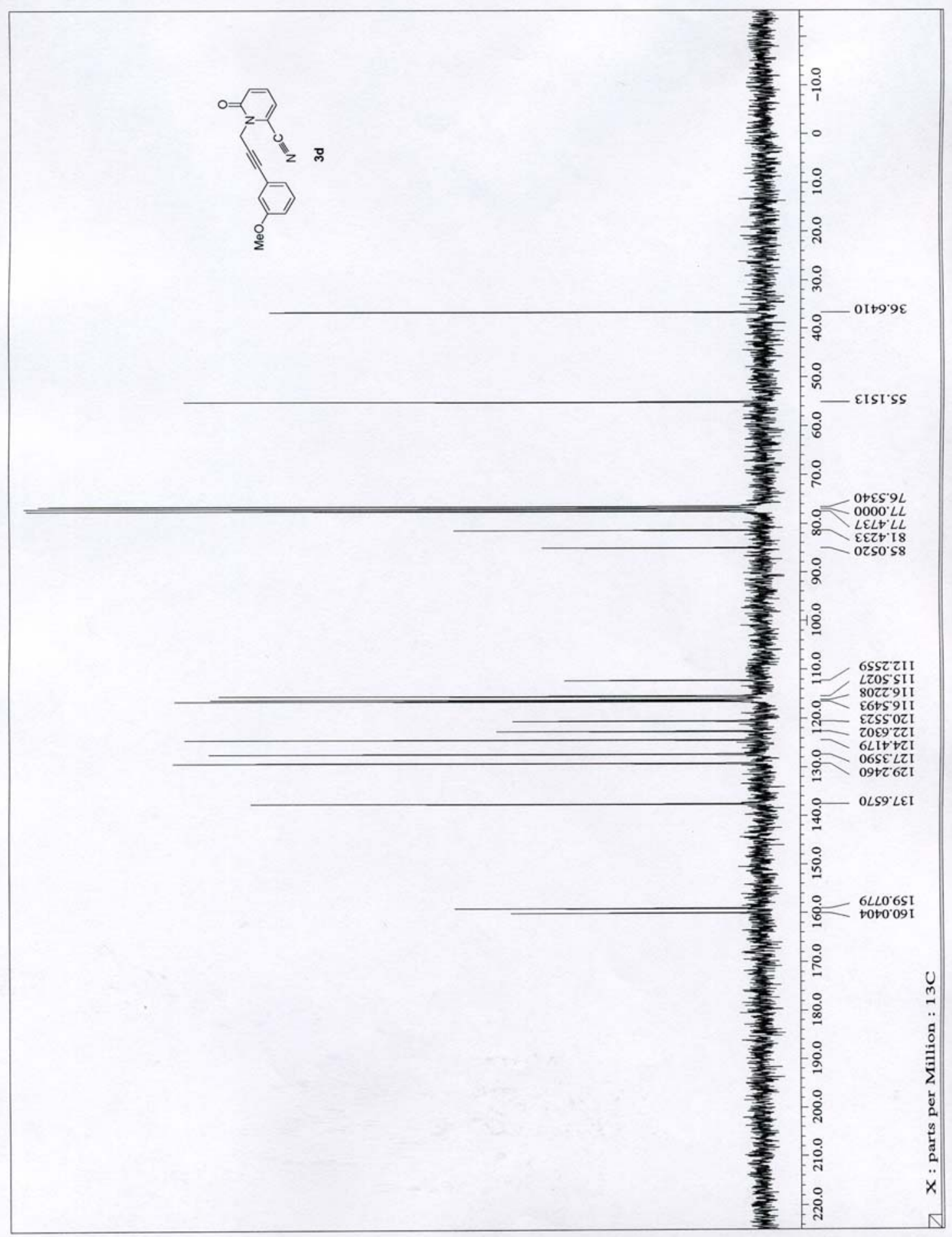




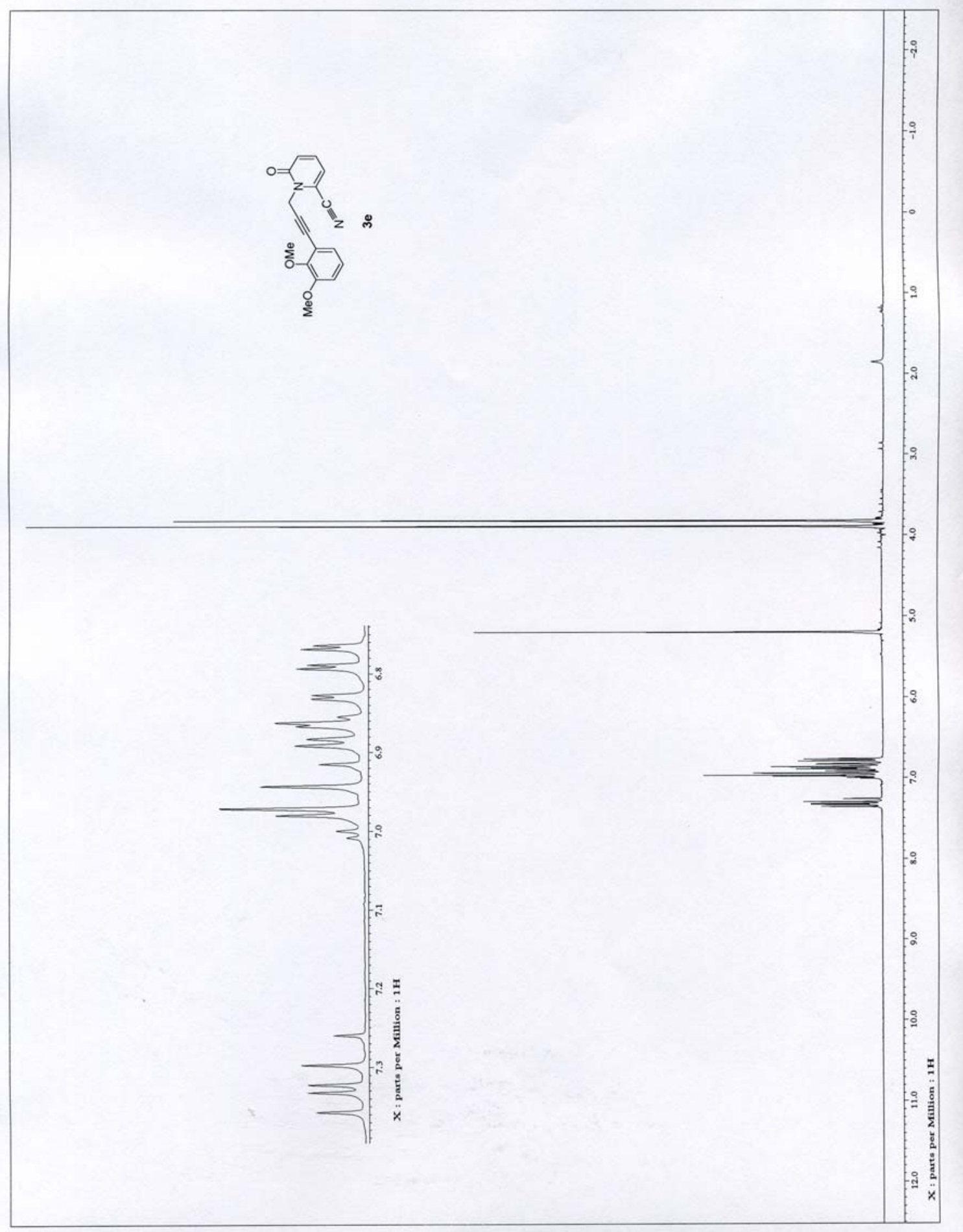




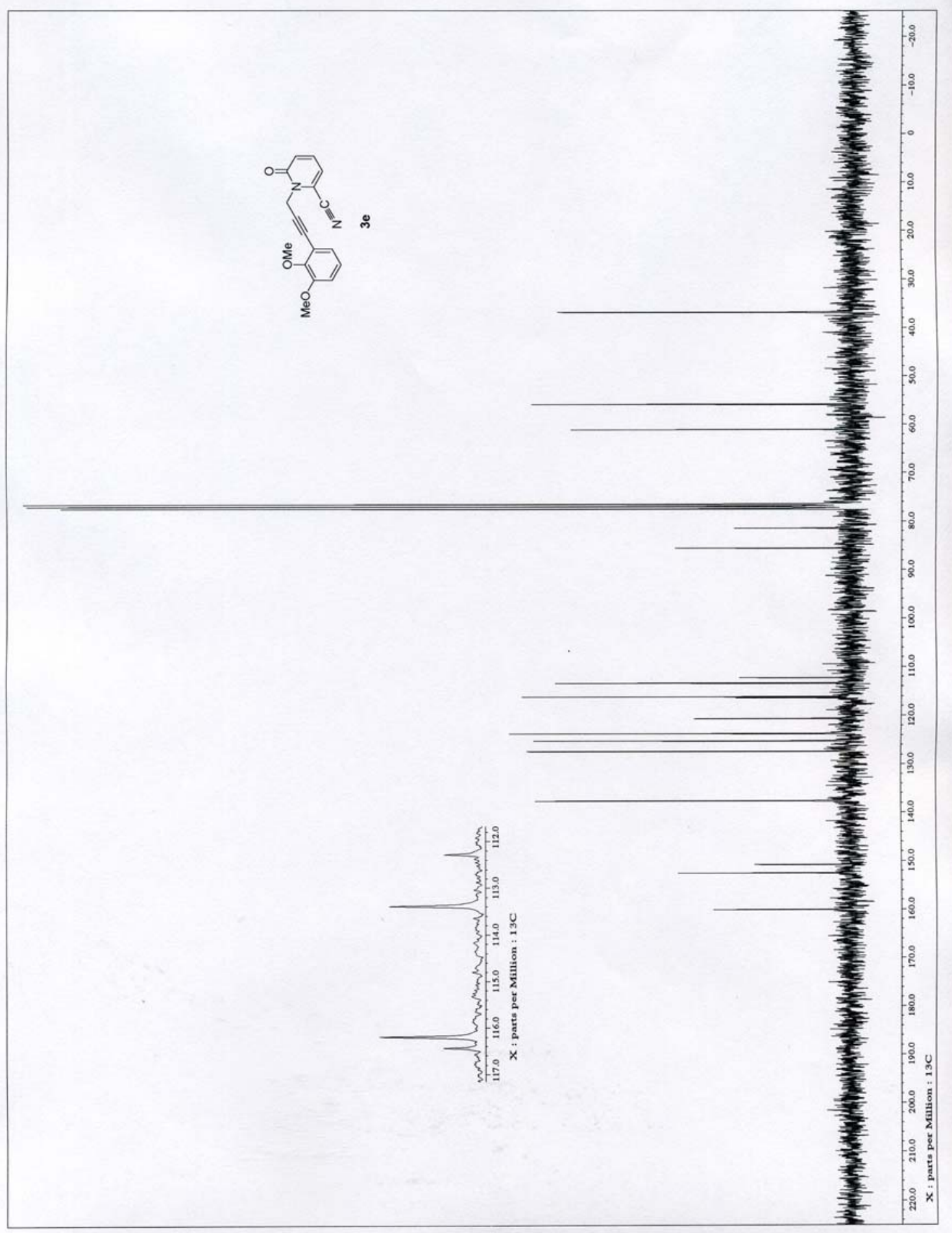




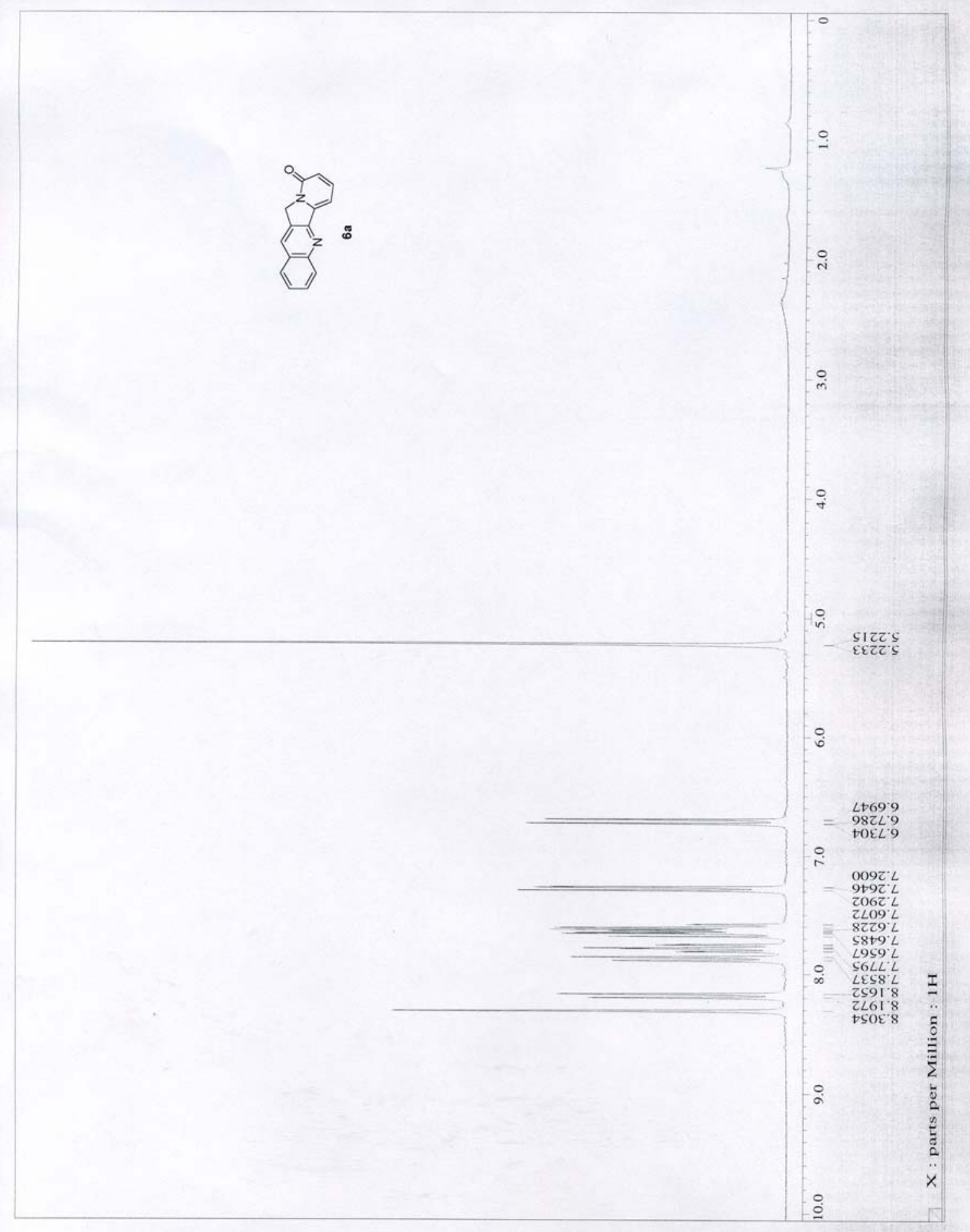




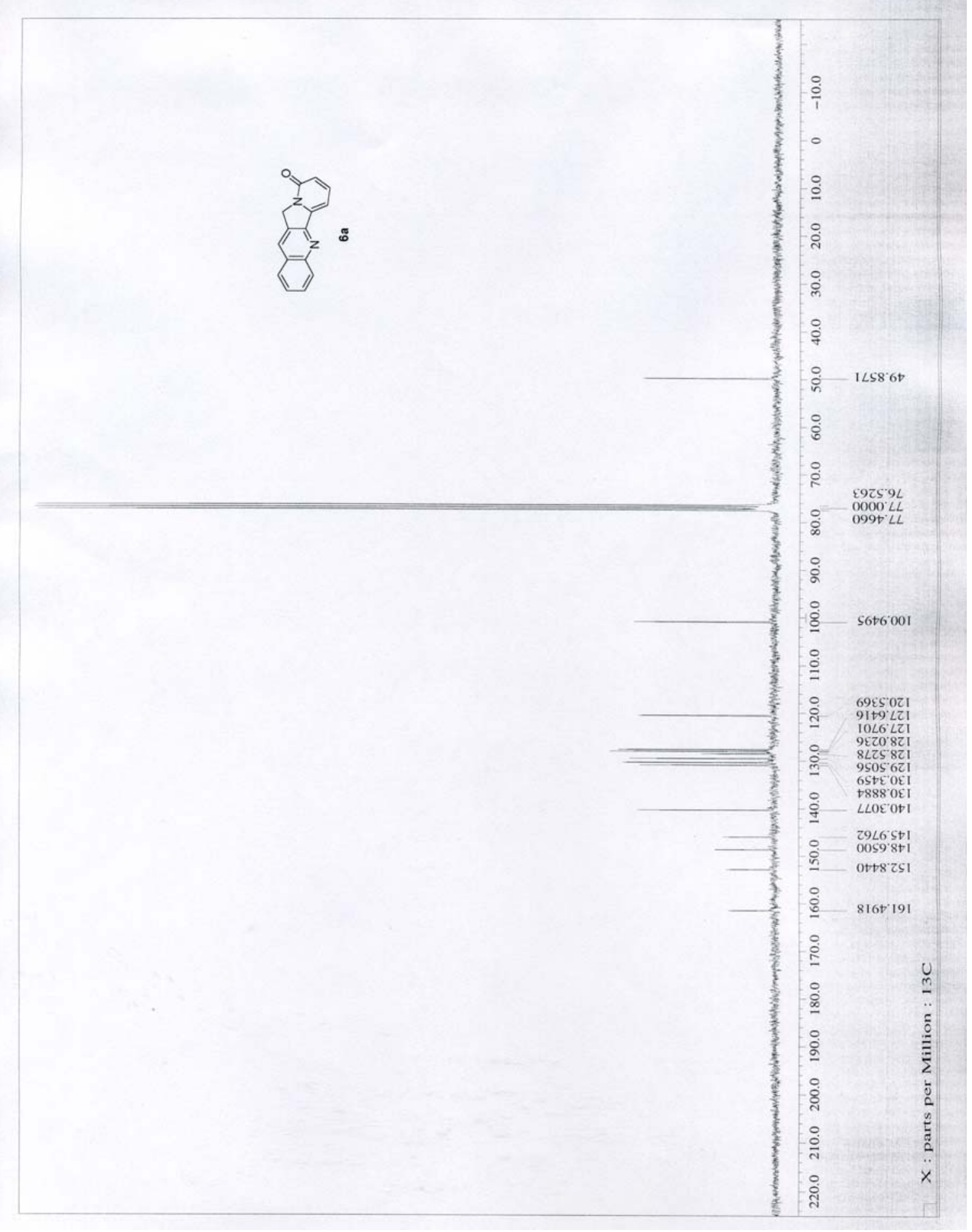




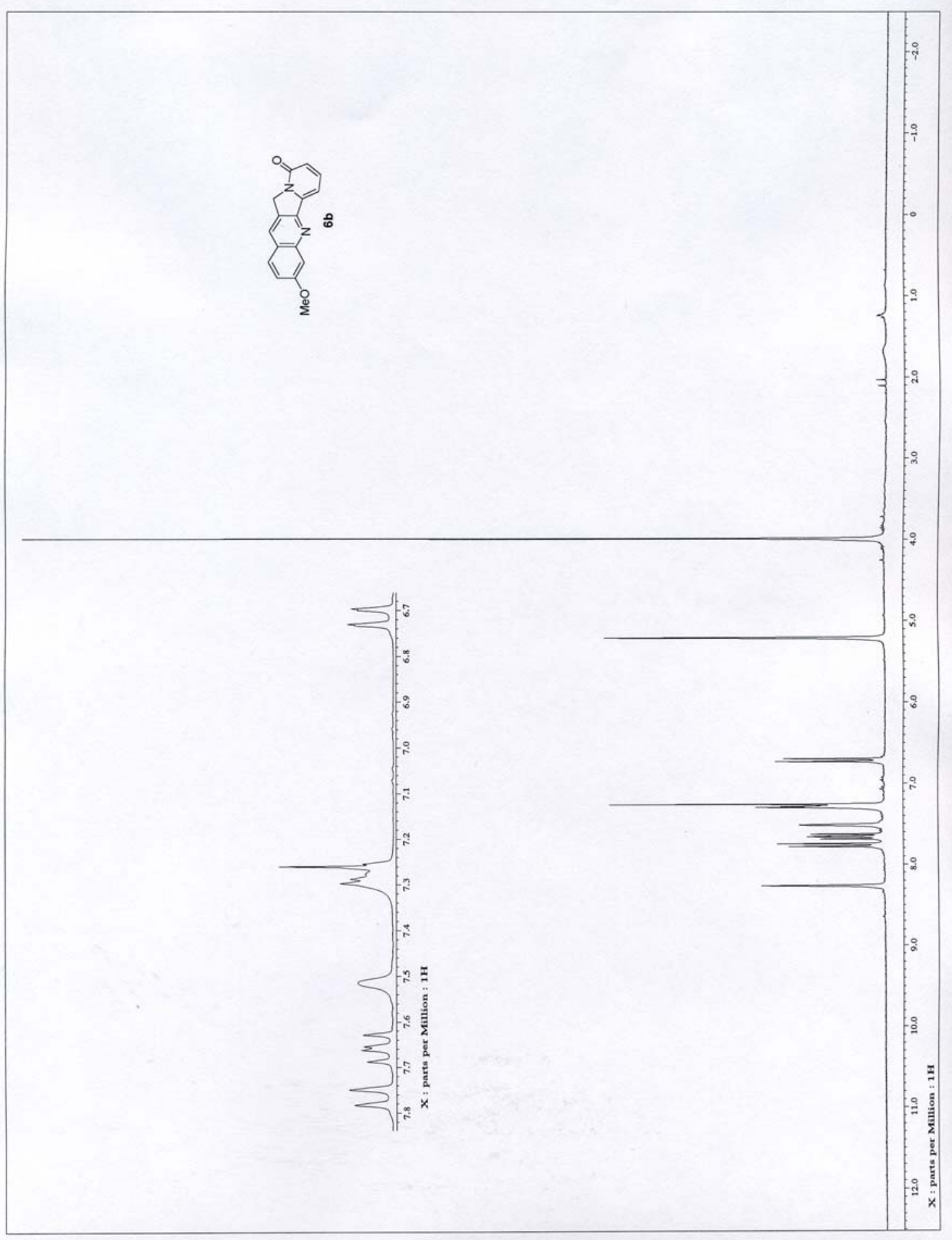




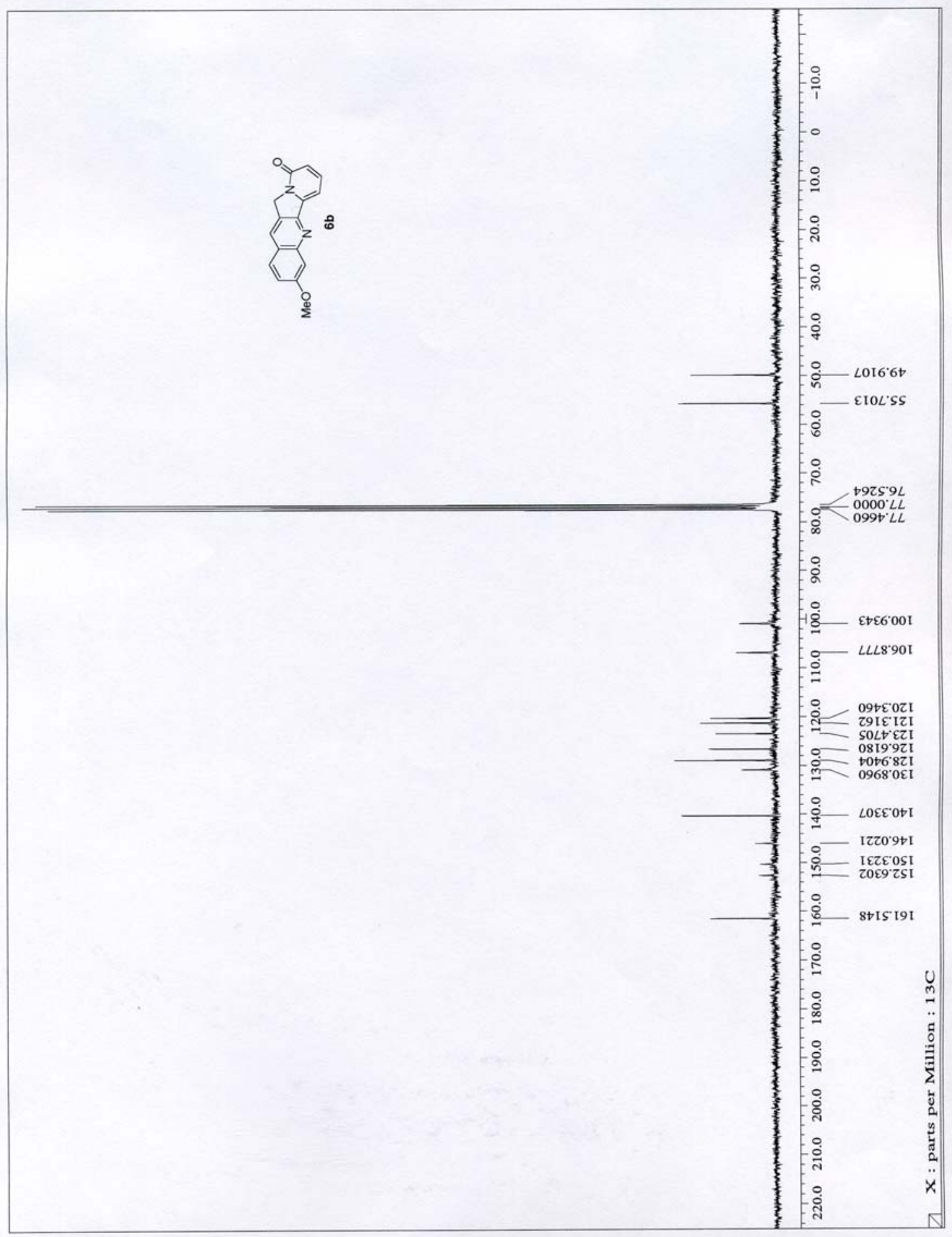




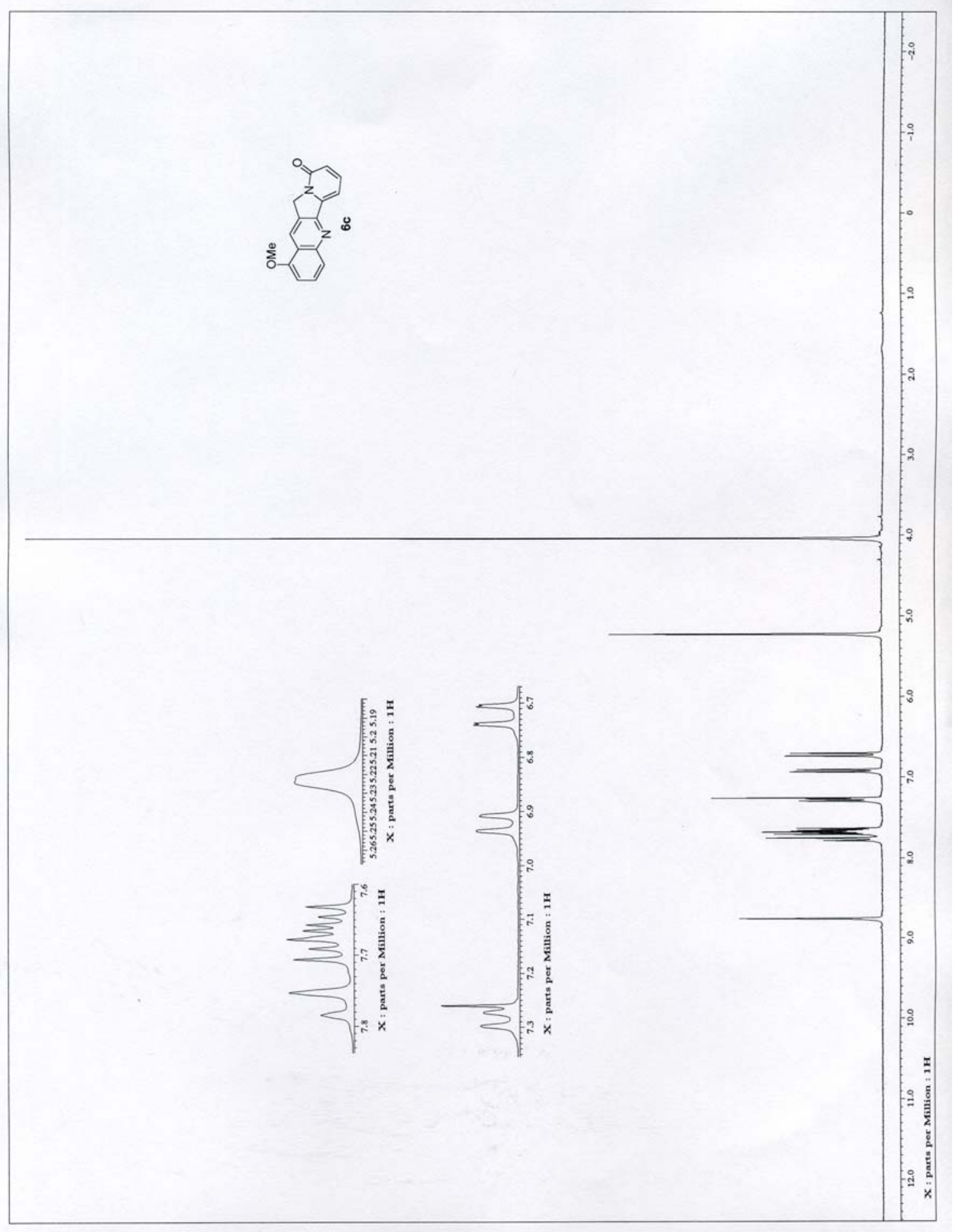




$$
1
$$




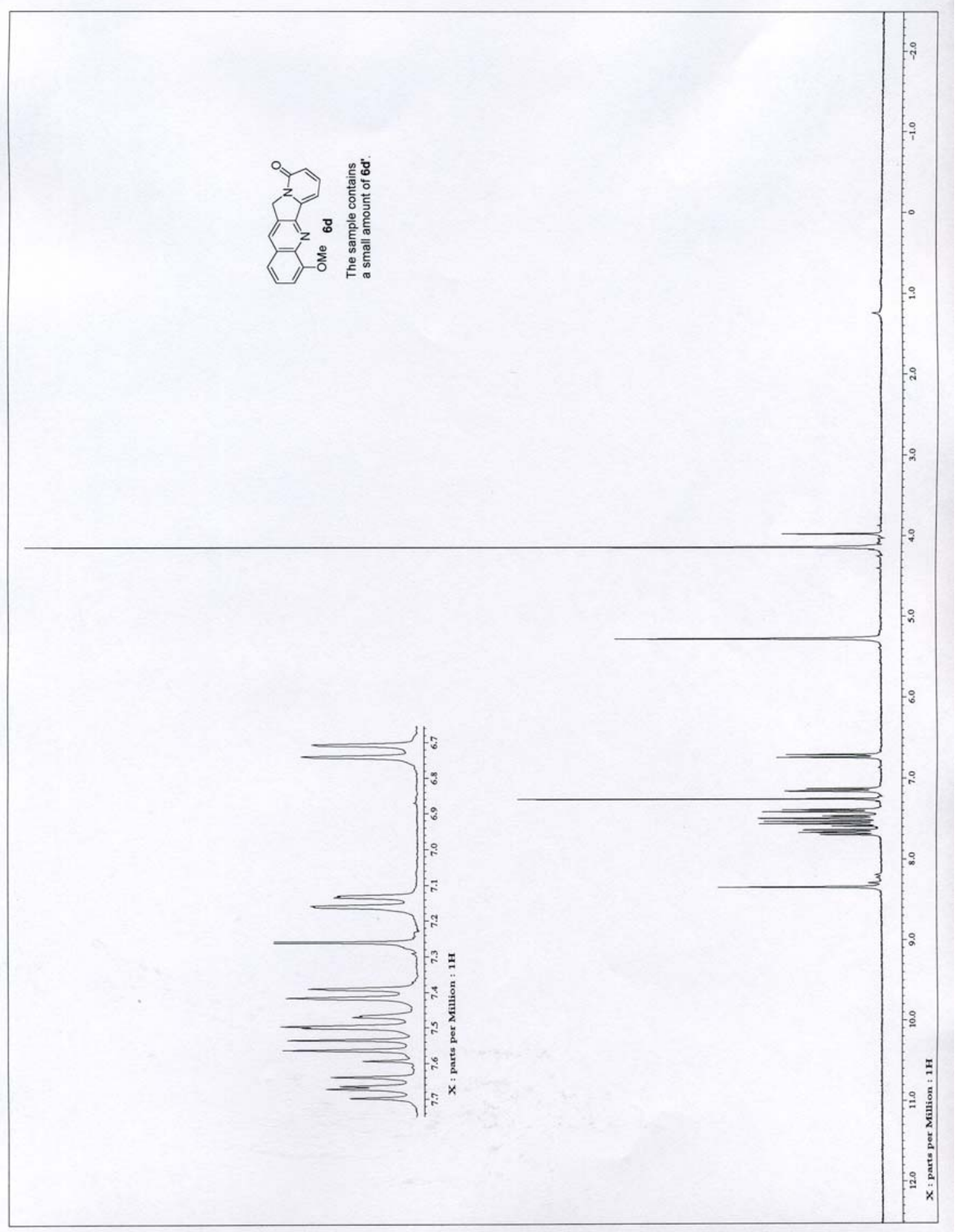




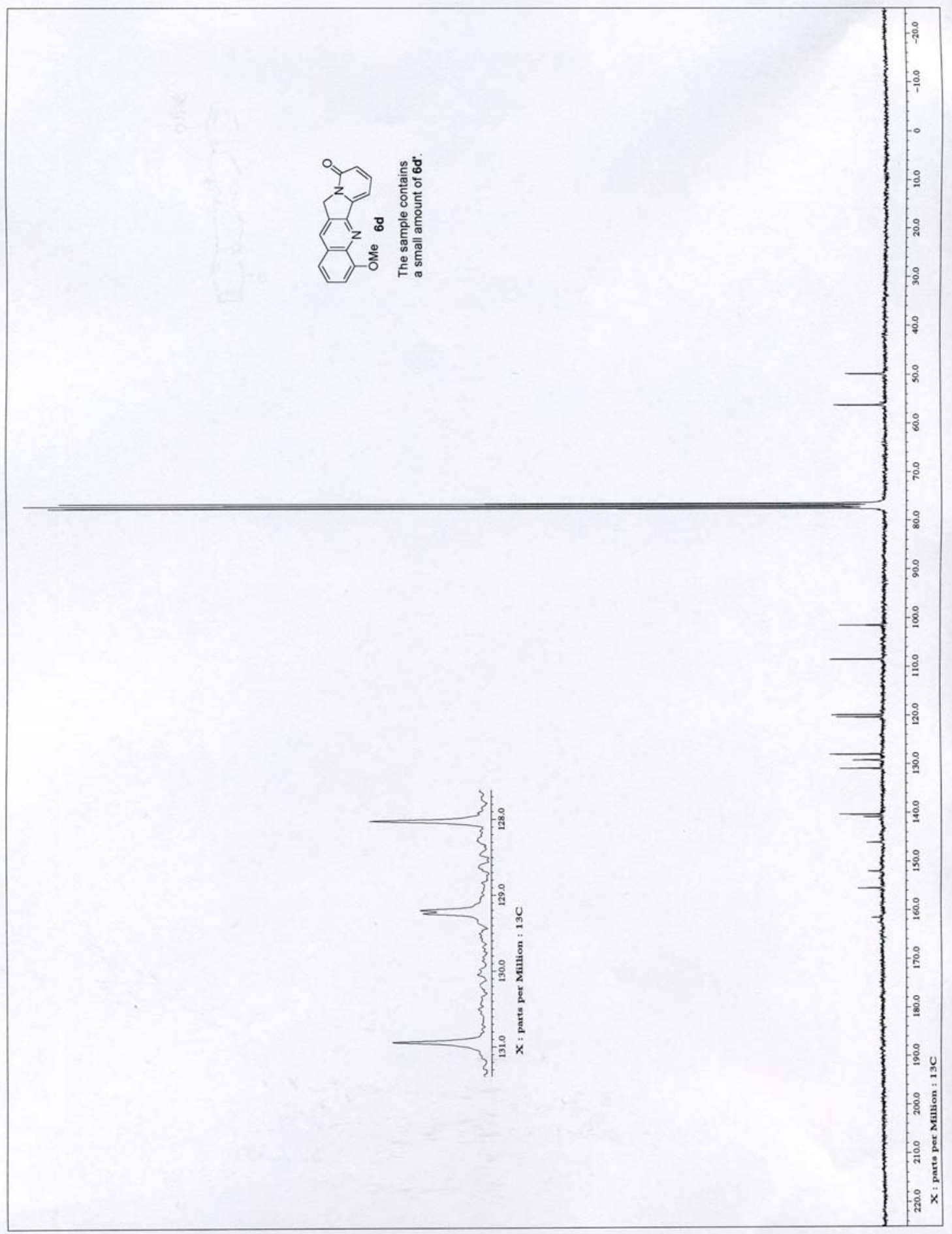




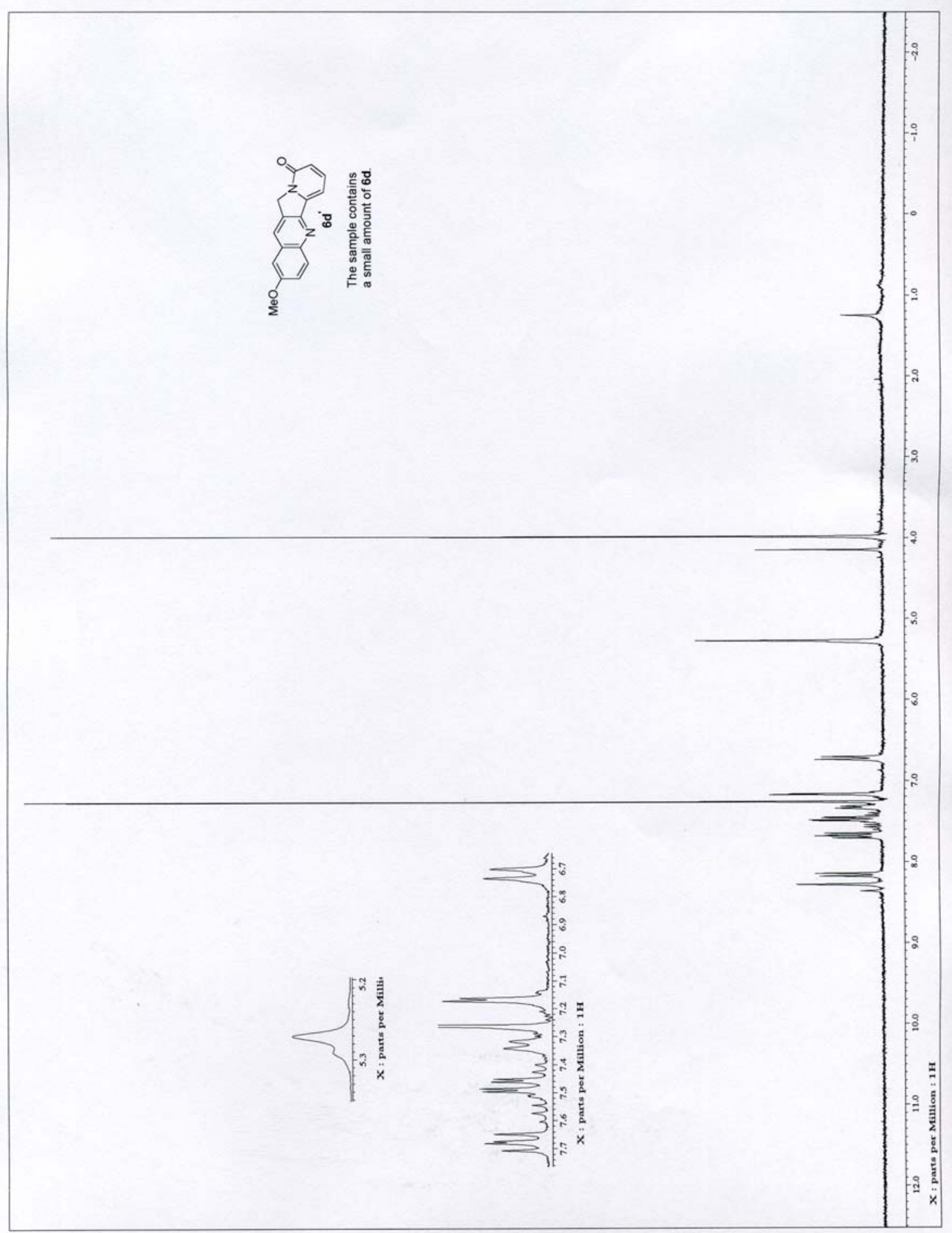




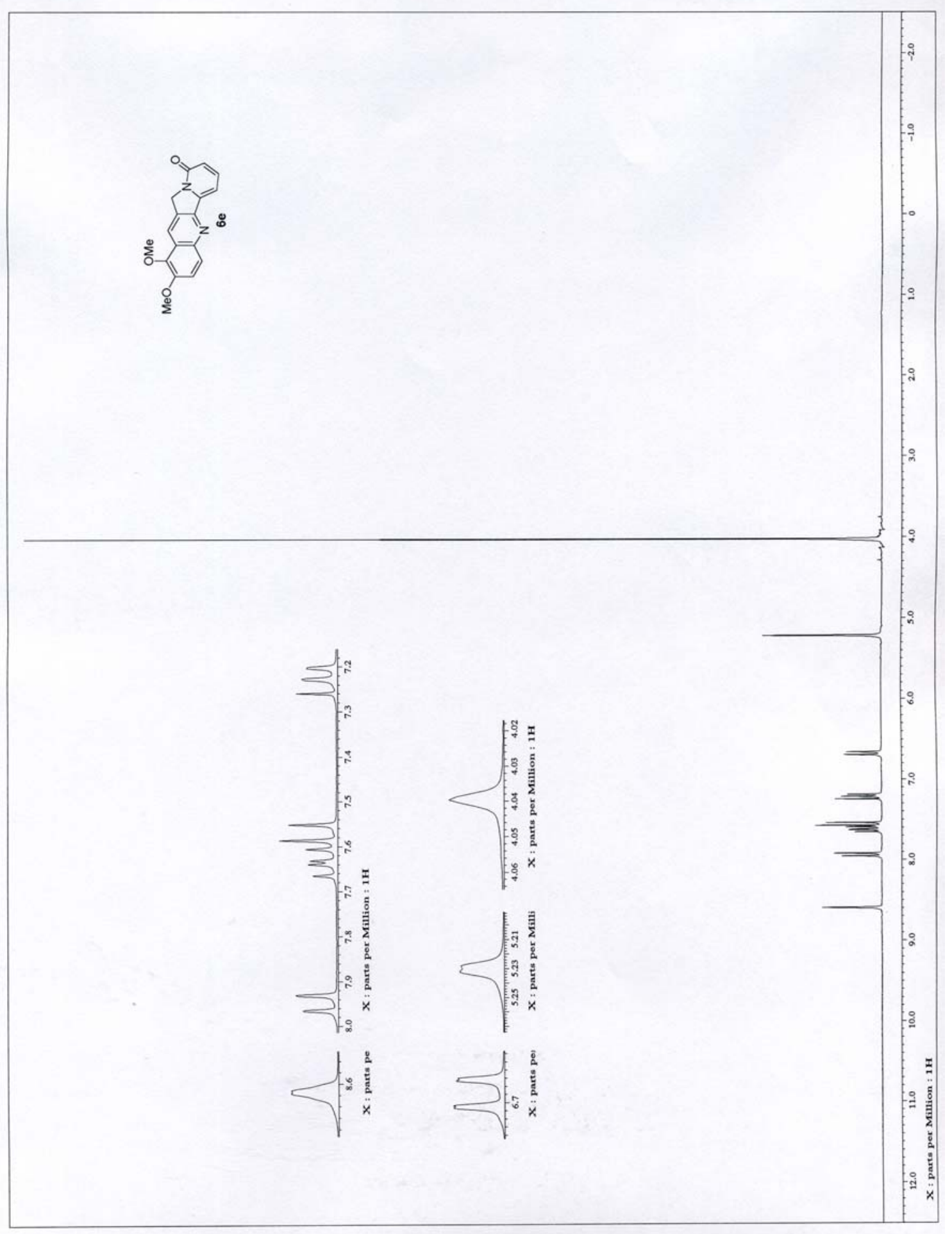




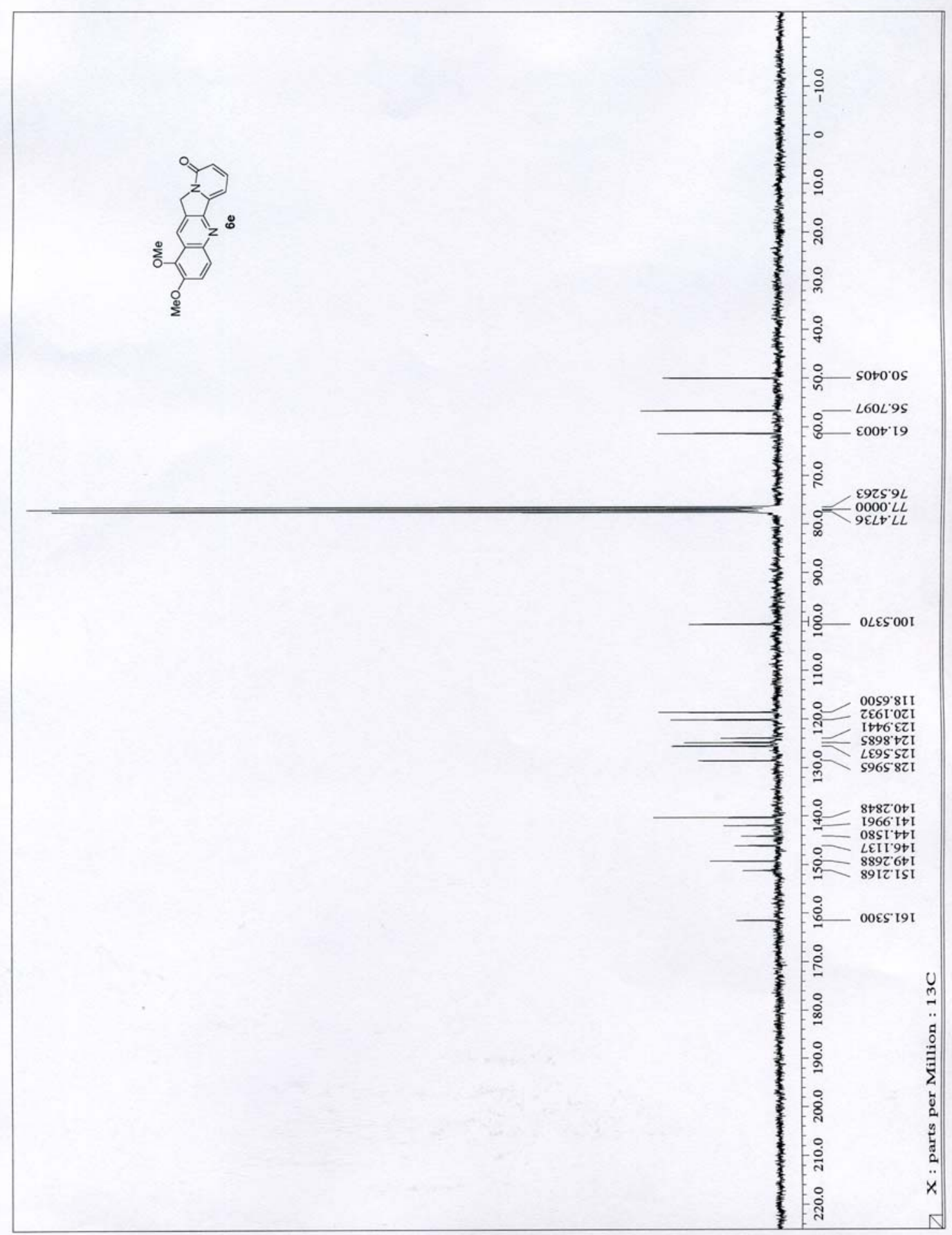



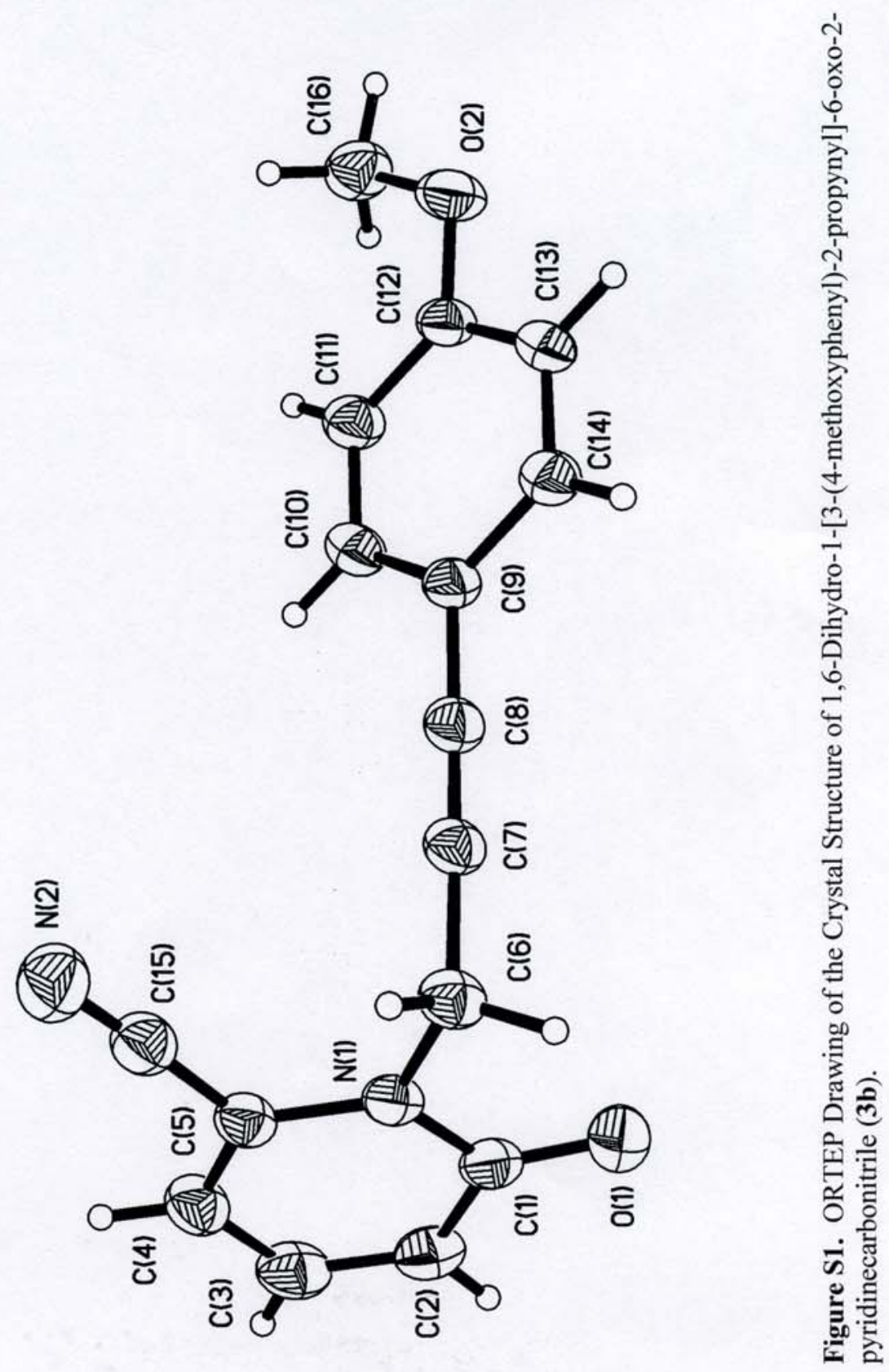


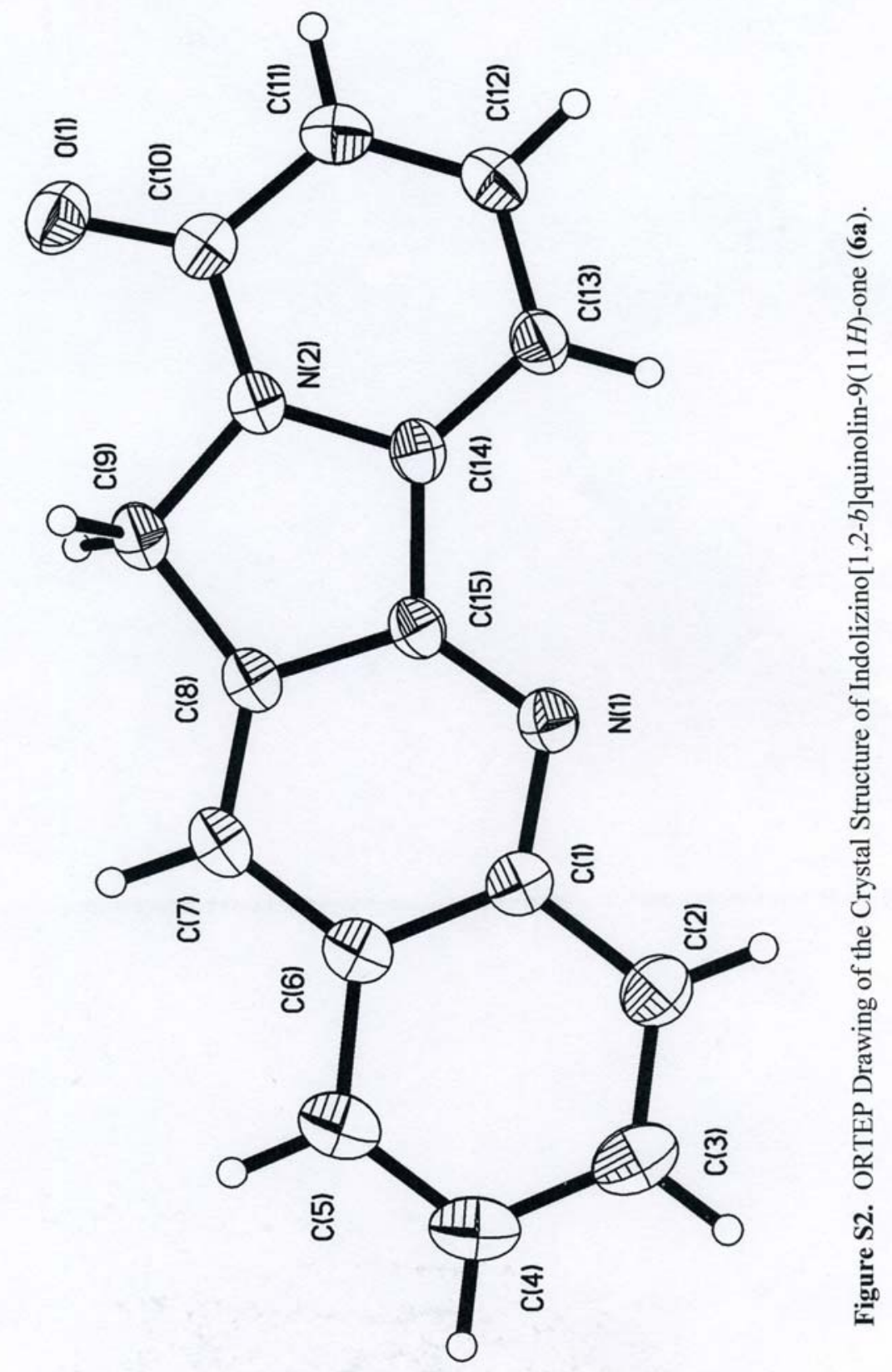



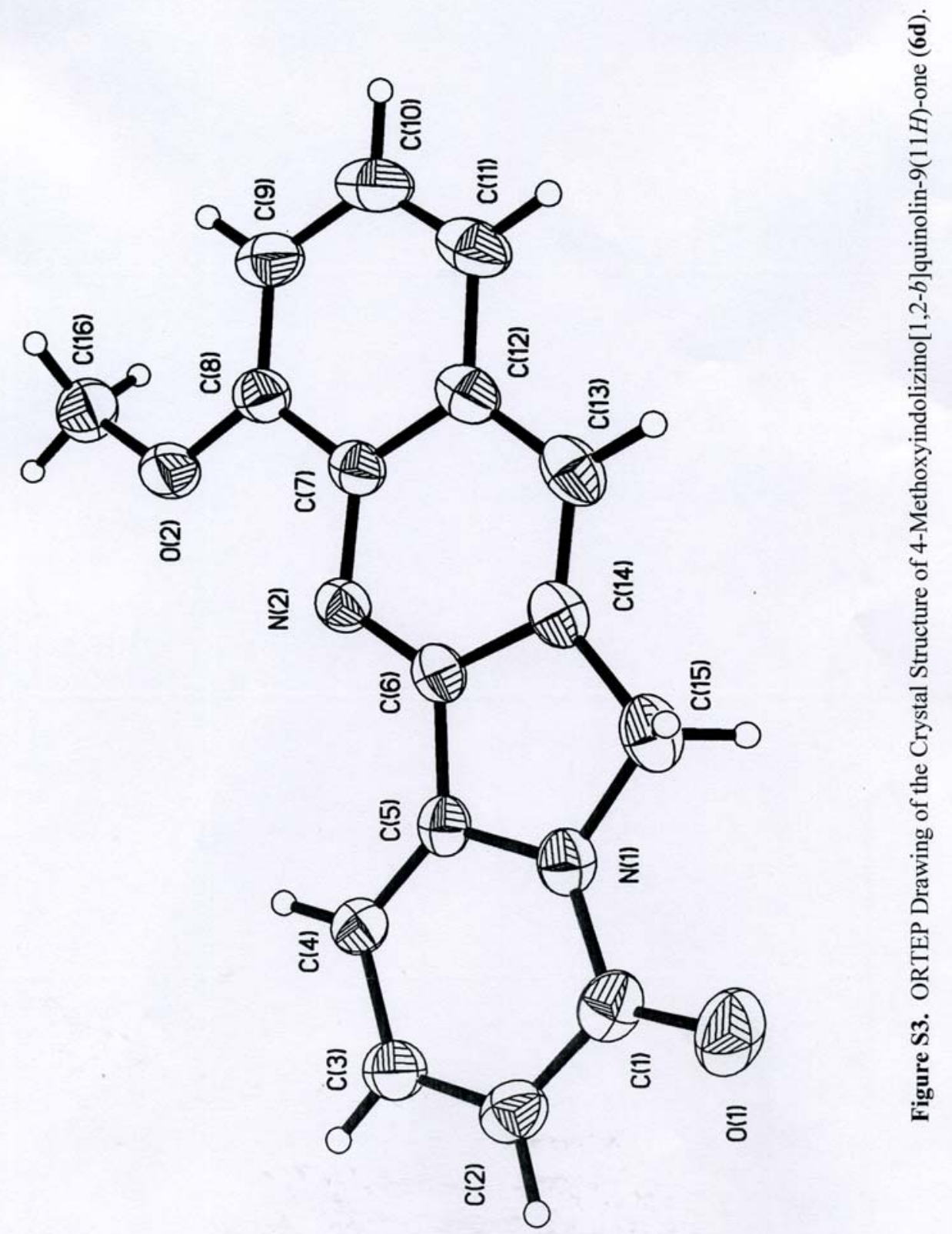